
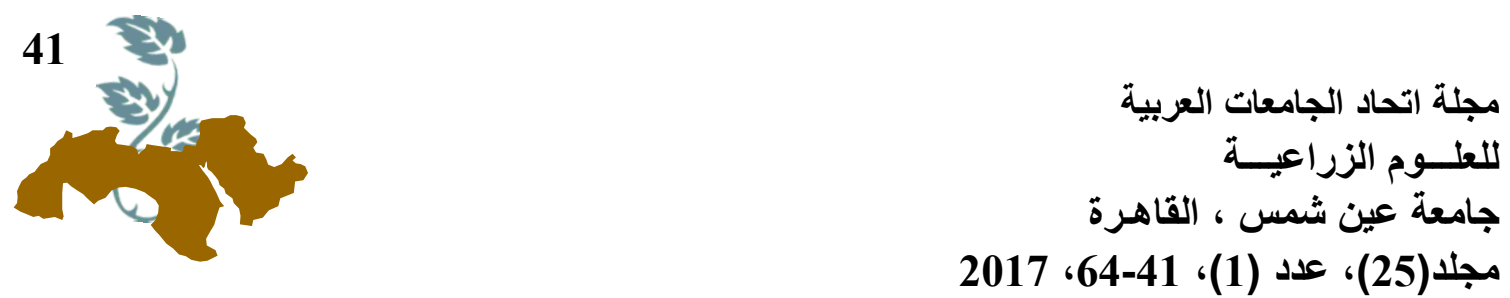

الزواج المبكر وأثره على تنظيم عملية الإنجاب

(دراسة ميدانية فى ريف محافظة الثرقية)

[3]

هاى أحمد علوان الايب - سحر كحم شلبى نويصر

شعبة الاجتماع الريفى والإرشاد الزراعى (اجتماع ريفي) - قسم الإقتصاد الزراعى - كلية الزراعة - جامعة الزقازيق - مصر تونر

البسيط لبيرسون، ومعامل التوافق لإختبار معنوية العلاقة الإقترانية، وحساب الفجوة التطبيقية.

وتوصلت الدراسة لمجموعة من النتائج أهمها:

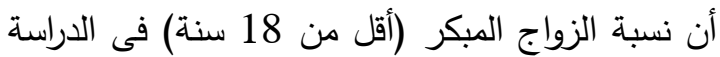

الميدانية بلغت 36.3\%، وتبين أن نحو 43.5\%؛

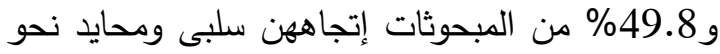

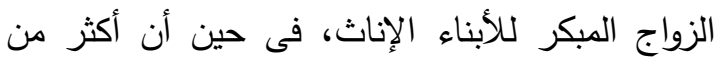

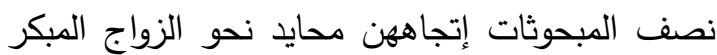

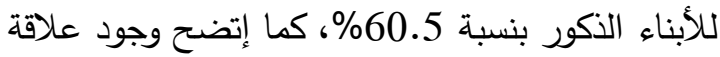

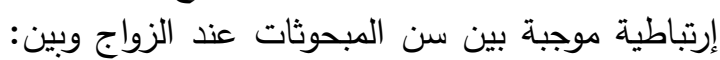
عدد سنوات تعليم المبحوثة، وعدد سنوات تعليم الزوج، النيات

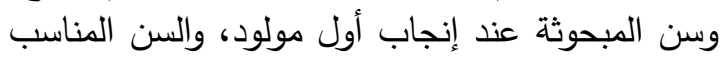

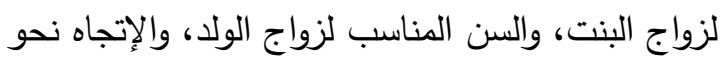

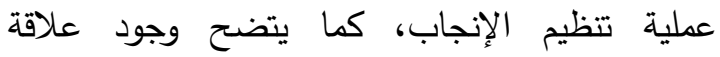
إرتباطية سالبة بين سن المبحوثاتية الإنات عند الزواج وبين:

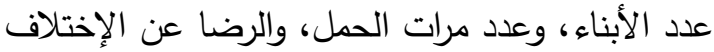

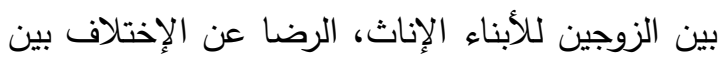

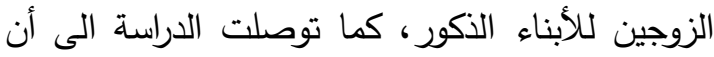

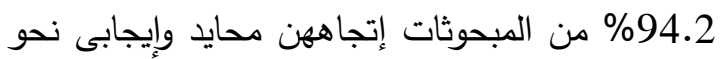

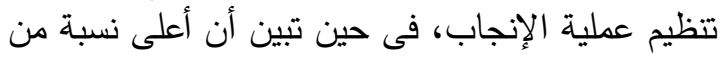
المبحوثات درجة تفضيلهن وتطبيقهن لوسائل تتظين الإني

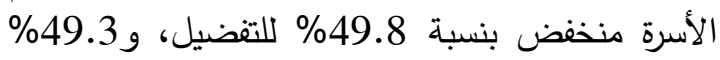
للتطبيق، ويتضح وجود فجوة ما بين تطبيق المبحوثات
الكلمات الدالة: الزواج المبكر، تتظيم عملية الإنجاب، وسائل تنظيم الأسرة، محافظة الشرقية

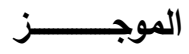

هدفت الدراسة الى التعرف على أسباب الزواج

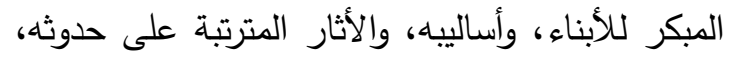

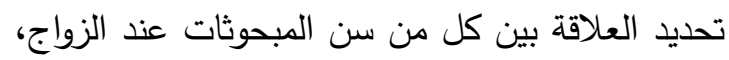

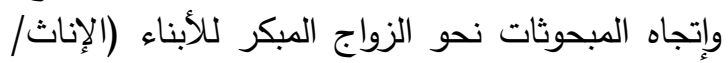

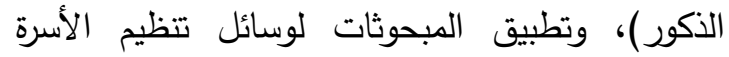
(كمتغيرات تابعة) وبين مجموعة المتغيرات الديموجرافية لإنية والإقتصادية والإجتماعية المينة المدروسة (كمتغيرات

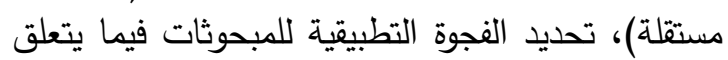

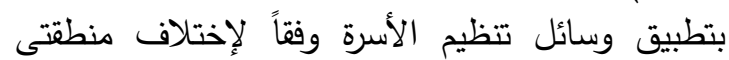

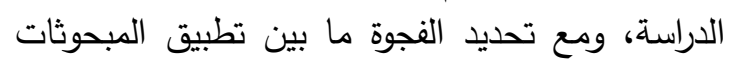

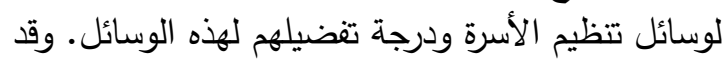

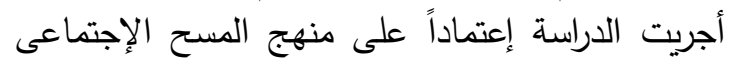
بقريتى كفر أبو نجم، وأولاد العدوى بمحافظة الشرقية الثراتية

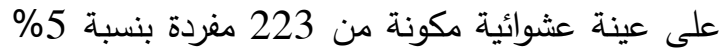

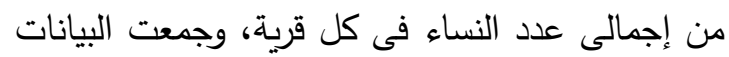

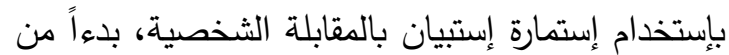

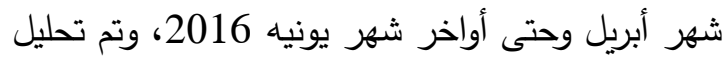

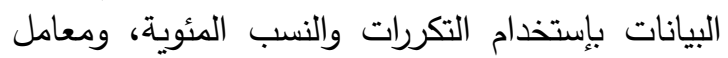

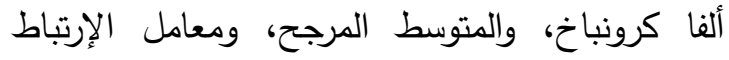

\footnotetext{
(تسليم البحث فى 21 سبتمبر 2016)

(مراجعة البحث فى 2 نوفمبر 2016 2نابتير 2016) (الموافقة على البحث فى 9 نوفمبر 2016 نوفير 2016)
} 
خلال الزواج، فى حين أنه من الأمور الأساسية لإنجاح

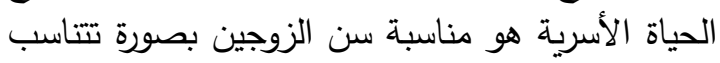

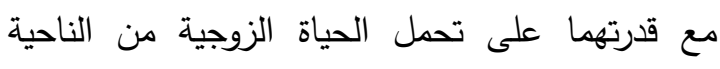

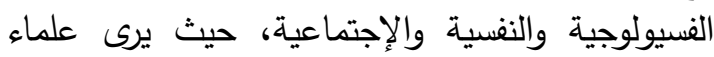
طب النساء أن أفضل سن للإنجاب عند المرأة ما بين علين

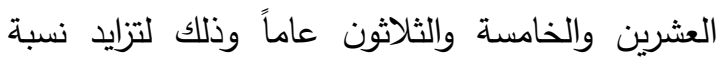

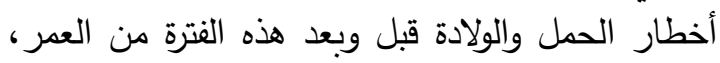

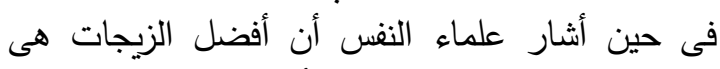

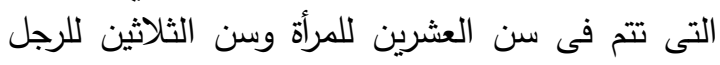

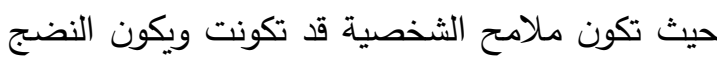

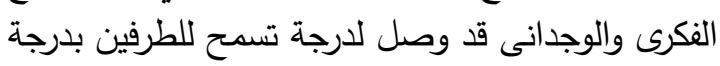

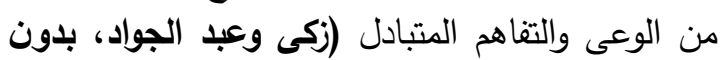

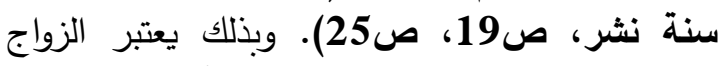

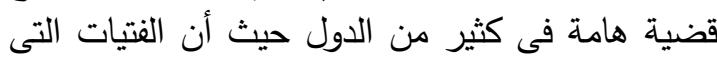

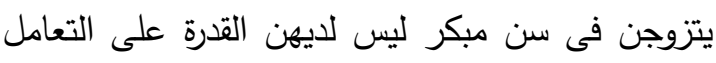

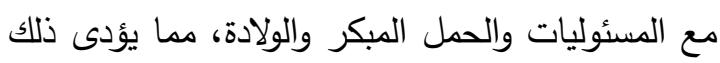

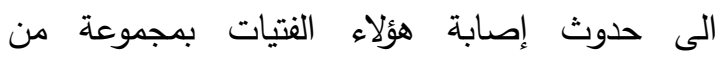

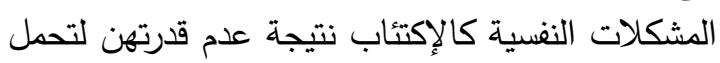

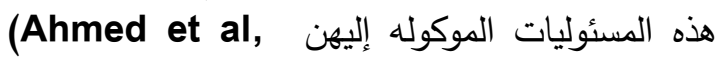
(2013, p84)

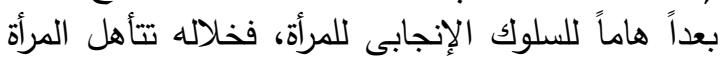

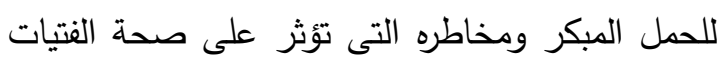
(Singh and Samara, 1996, الصغيرات (p148) ولذلك يجب أن يتم الزواج فى سن يكون فيه

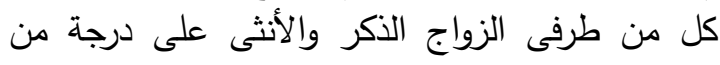

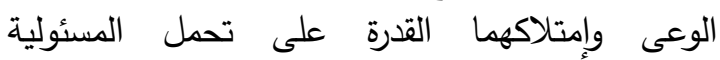
الإقتصادية والإجتماعية التى سوف تقع على على عاتقهما (الزيود، 2012، ص436)، ومن هنا وجب الإهتمام

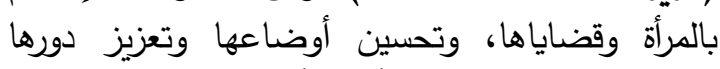

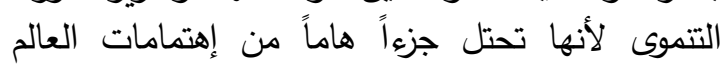

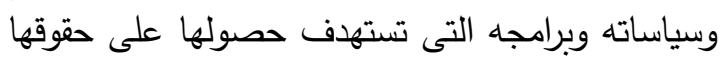

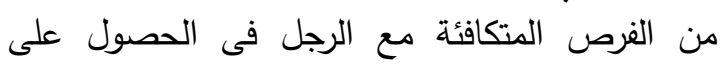

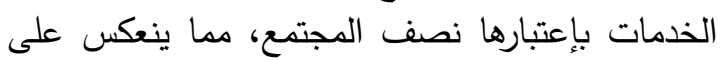

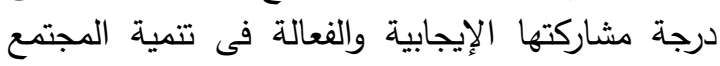

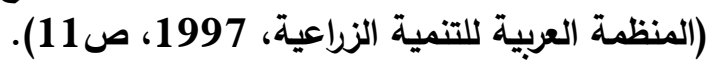

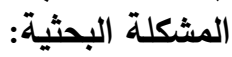
يعتبر الزواج سنة الله فى خلقه فهو أهم النظم

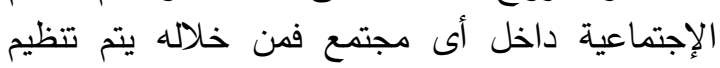
العلاقات الإجتماعية بين الأفراد، وتحقيق الإستقرار
لوسائل تتظيم الأسرة وبين درجة تفضيلهن لهذه الوسائل وهذه الفجوة لصالح محور التطبيق.

\section{المقدمة}

خلق الله سبحانه وتعالى الإنسان وجعل منه الذكر

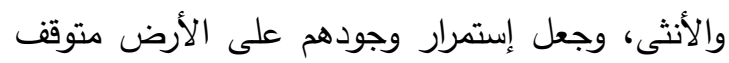

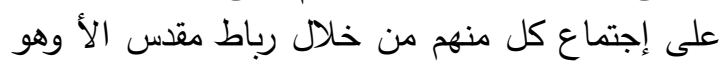

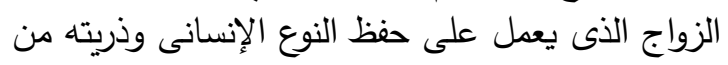

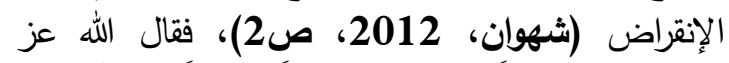

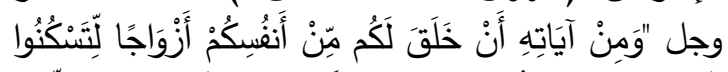

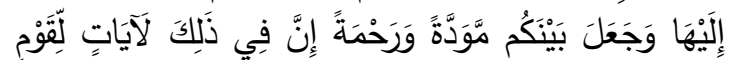

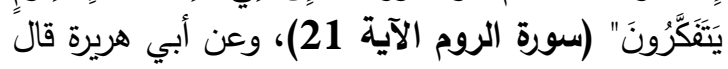

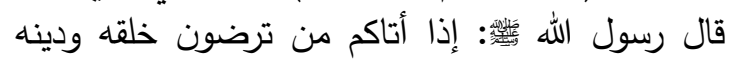

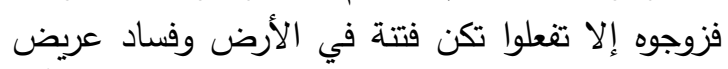

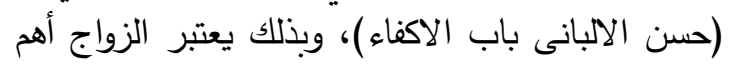

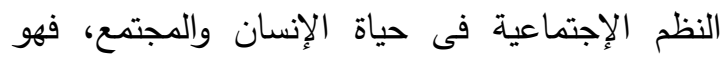

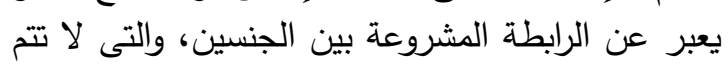

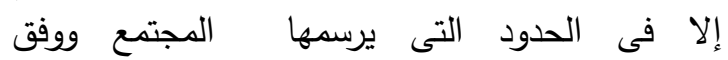
المصطلحات والأوضاع التى يقرها (الخثاب، 1037) 1987، صا103)، وهناك إرتباط كبير بين مصطلح الزواج

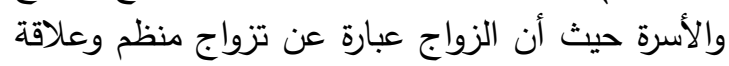

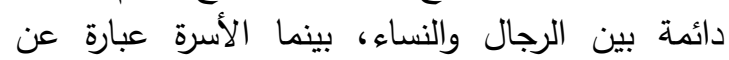

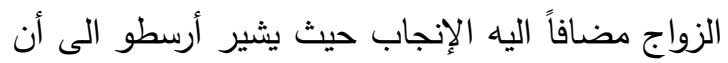

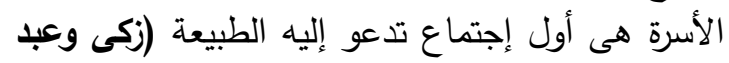

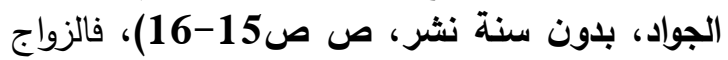
هو الوسيلة الشرعية لبناء الأسرة التى يشبع من خلالها

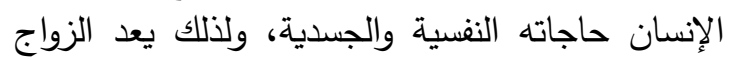

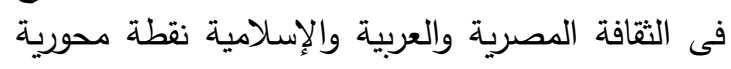
حيث يمنح كلا الزوجين المكانة الرفيعة والإحترام

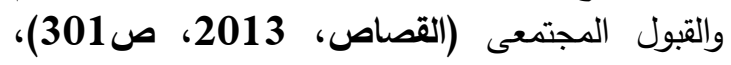
ويعد الزواج الركيزة الأساسية التى يقوم عليها بناء الأسرة، وعلى الرغم من القوانين التى نصت لألى على تحديد

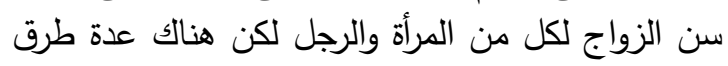

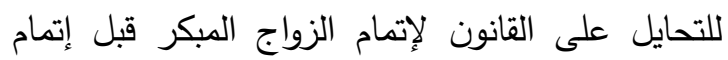
شروط القانون للمتزوج (الطائى والزبيدى، 2014، الكيكر

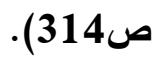
ففى المجتمعات الريفية يتزوج كل من الثاب والفتاة فى سن مبكرة لتحقيق مكانة إجتماعية لا تتحقق الإمن التمن 
المحافظات من حيث عدد السكان بعد محافظتى القاهرة

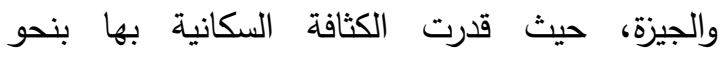
1376.3 نسمة/ كم² (الجهاز المركز للتعبئة العامة صلئة

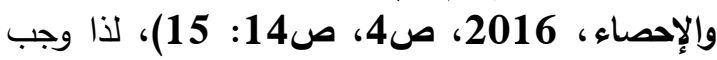

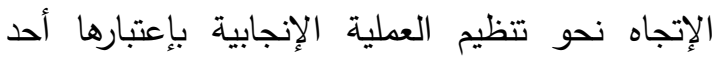

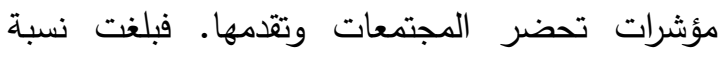

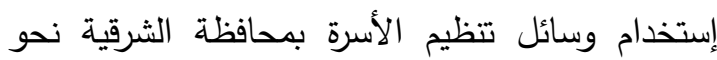

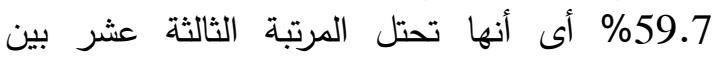

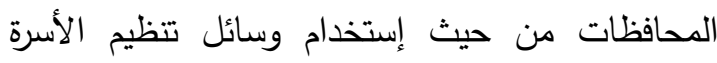

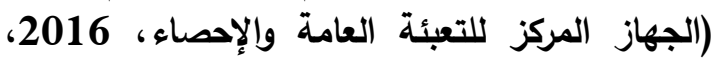

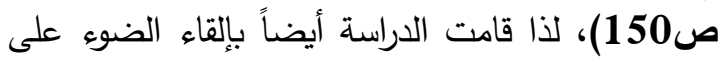

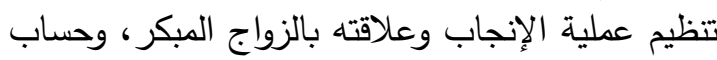

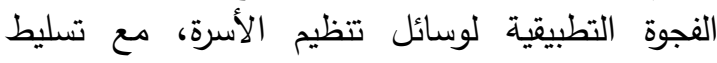

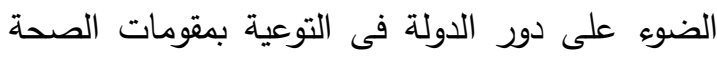
الإنجابية للنساء.

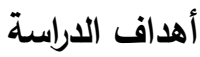

إتساقاً على ما ورد فى المشكلة البحثية تستهدف الدراسة الراهنة ما يلى: التى

1- التعرف على أسباب الزواج المبنة المبكر للأبناء، وأساليبه، والأثار المترتبة على حدوثه.

2- تحديد العلاقة بين سن المبحوثار المترتة على عدوثه الزواج وبين

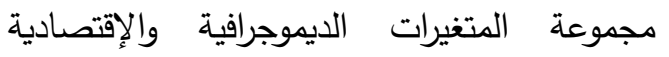
والإجتماعية التالية: المهنة، وعدد سنوات التوات التعليم

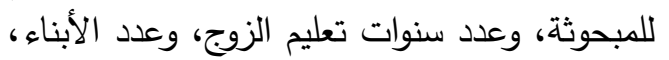

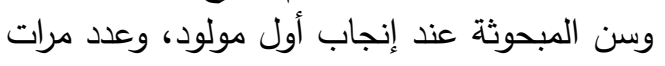

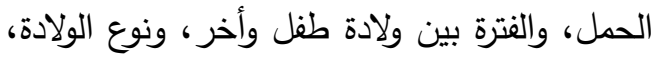

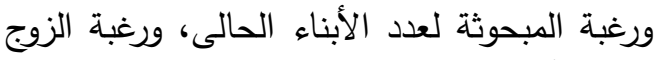

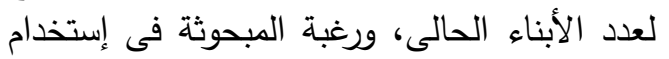

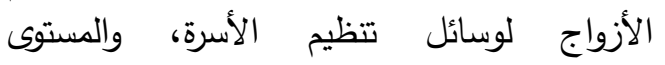

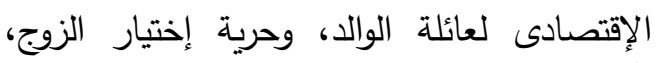

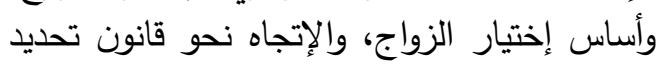

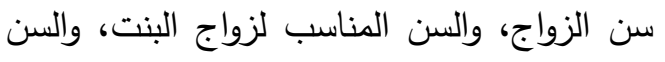

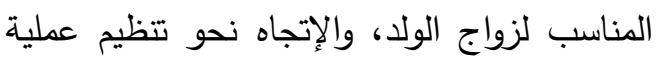

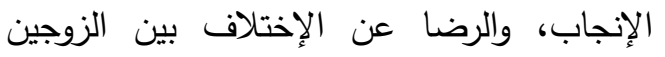

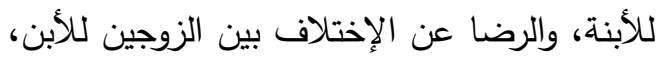
والمعرفة بإجراءات عقوبة الزواج المبكر . لإنداف
النفسى والإجتماعى والتوزان البيولوجى، كما أنه

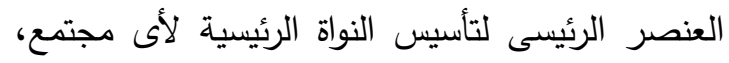

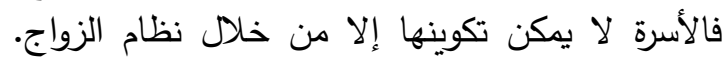

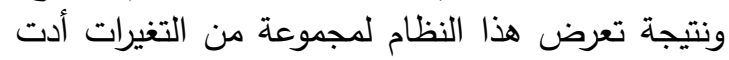

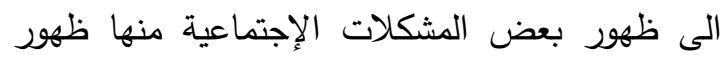

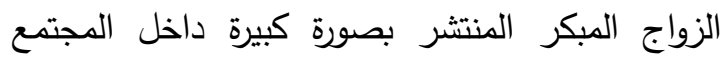

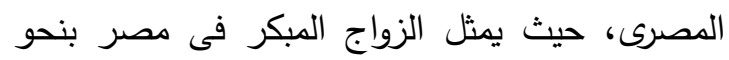

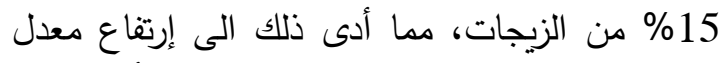

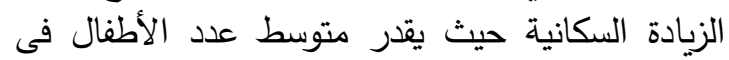
حالة الزواج قبل سن 18 سنة بـ 3.7، فئس فئ حين يقدر

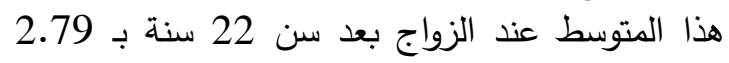

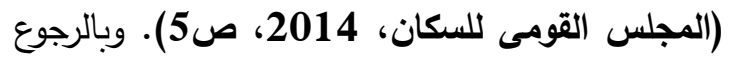

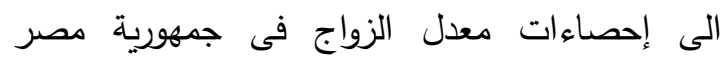

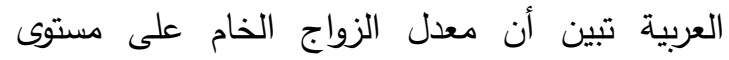

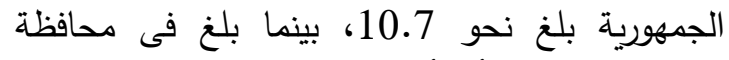

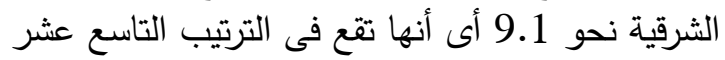
بين المحافظات من حيث معدل الزواج الخام، بمعدل فئرل

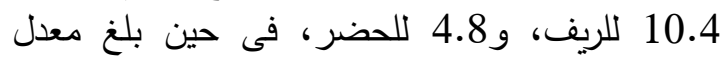

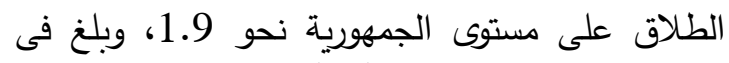
محافظة الثرقية نحو 1.4 أى أنها تحتل المركز الثرئ الثانى عشر بين المحافظات فى معدل الطلاق، بمعدل 1.4

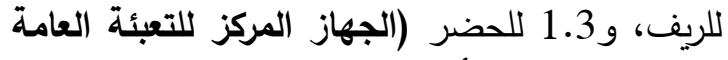

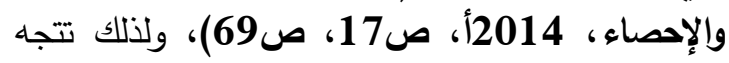

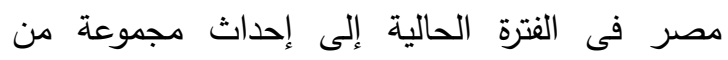
التغيرات الجذرية فى المجالات السياسية والإجتماعية

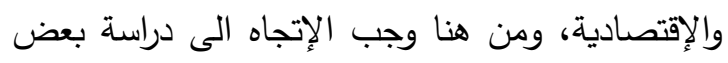

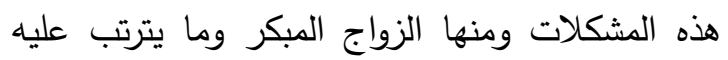

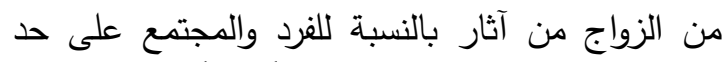

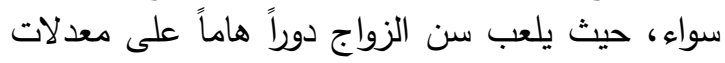

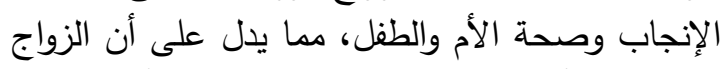

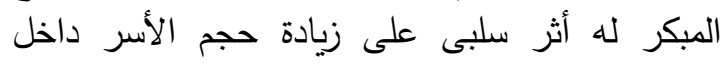

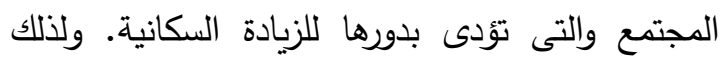

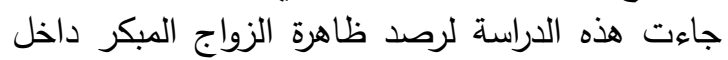

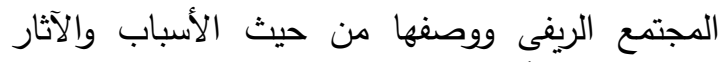

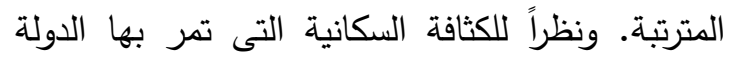
المصرية حيث قدرت فى 2016/1/1 بنحو 89.2 نسمة/ كم²، وبلغ عدد السكان نحو 90086267

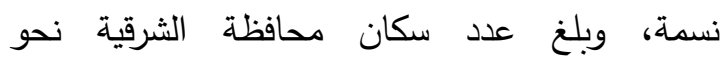
6640664 نسمة وبذلك فهى تحتل المرتبة الثالثة بين 


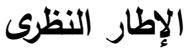

مفهوم الزواج The Marriage Concept: يعتبر الزواج الرابطة المشروعة بين الجنسين، وعن طريقه

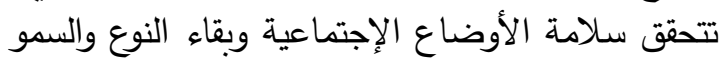
بالعلاقات بين النساء والرجال الى مستوى المشروعية الإنية والتتظيم بما يتقق مع القيم الإنسانية (الخشاب، 1987، ص111)، فالزواج هو علاقة الحب والمودة

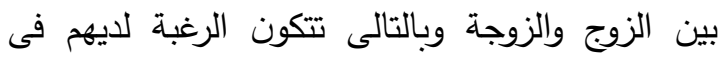

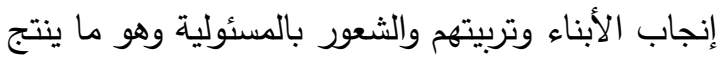

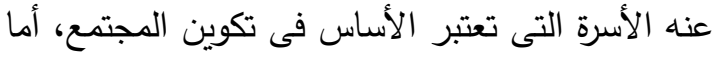

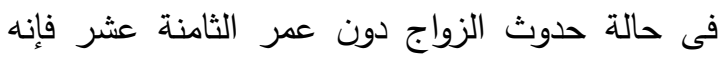
يعد نمطاً من أنماط العنف تجاه الأبناء (سليم وحارث،

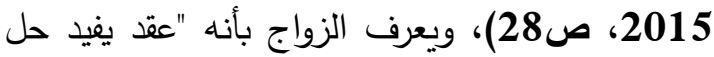

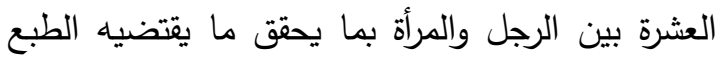
الإنسانى، أو أنه ميثاق شرعى بين الرجل الرجل والمرأة-

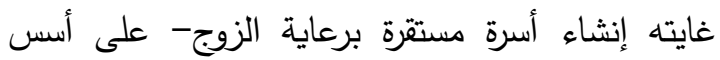

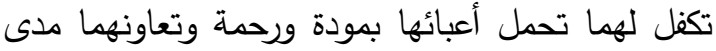

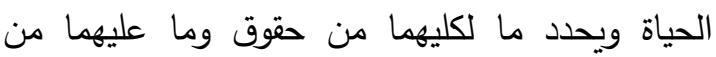

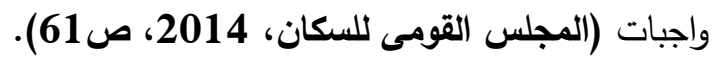
Early Marriage مفهوم الزواج Concept بإختلاف تحديد سن الزواج حيث يعتبر سن الزئ الزواج

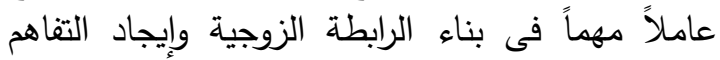

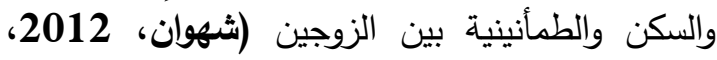

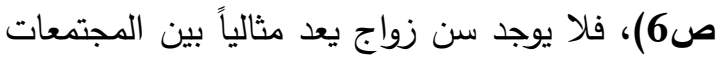

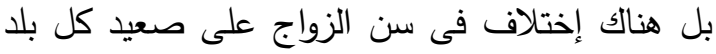
وفقاً لإختلاف الثقافات الإنسانية داخله (السبعاوى،

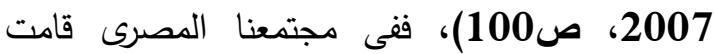
الحكومة عام 2008 برفع سن زواج الفئي الفتيات من 16

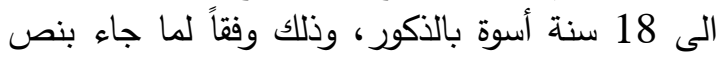
المادة 31 مكرر من الأحوال المدنية رقم 143 لسنة 1994 والتى تمنع توثيق عقد الزواج قبل سن 18 سنة، والمادة 228 من قانون العقوبات (المجلس

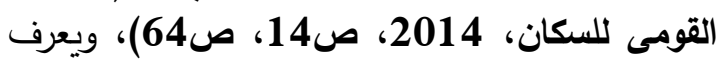
الزواج المبكر بأنه الزواج قبل سن البلوغ صنان (عفانه،

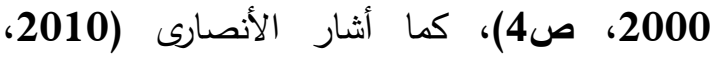
ص117) الى أن الزواج المبكر عبارة عن ظاهرة
3- تحديد العلاقة بين إتجاه المبحوثات نحو الزواج

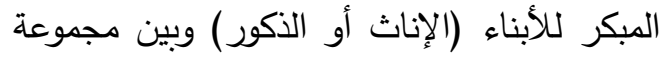
المتغيرات الديموجرافية والإقتصادية والإجتماعية ولائ الإنية التالية: المهنة، والدخل الثهرى للأسرة، وعدد

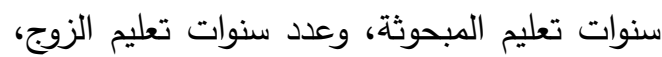

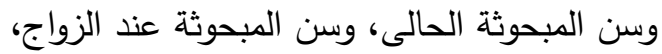

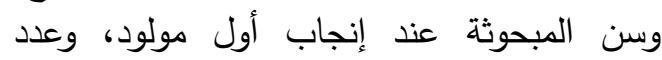

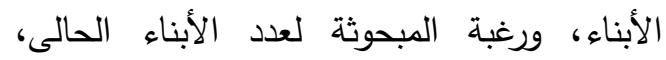

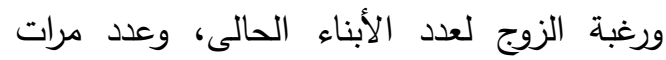

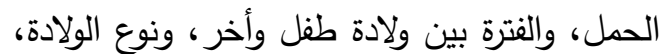

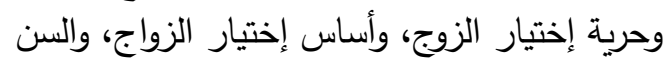

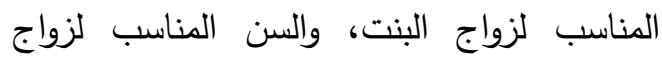
الولد، والمعرفة بإجراءات عقوبة الزواج المبكر، الزباج والرضا عن الإختلاف بين الزاء الزوجين للأبناء

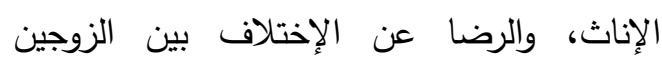

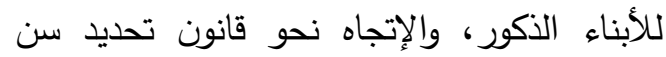

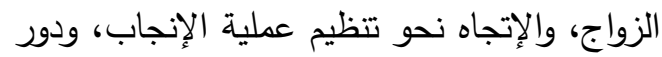
الدولة فى التوعية بمقومات الصحة الإنجابية للنساء. 4- تحديد العلاقة بين درجة تطبيق وسائل تنظيم

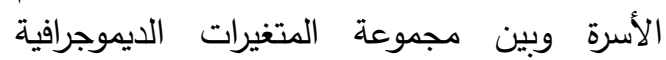
والإقتصادية والإجتماعية التالية: المهنة، والدخل

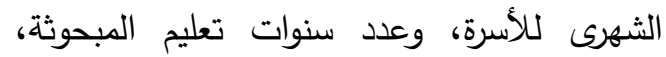

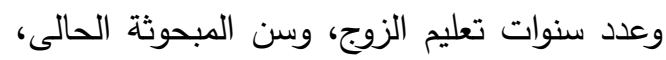

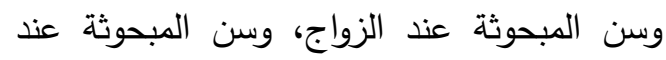
إنجاب أول مولود، وعدد الأبناء، ورغبة وندية المبحوثة المبنة

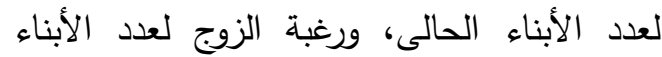

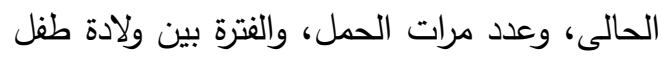

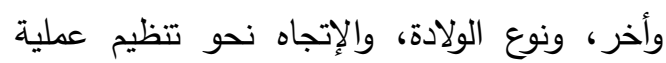
الإنجاب، والرغبة فونى إلولادة والإتخدام الأزواج لوسائل

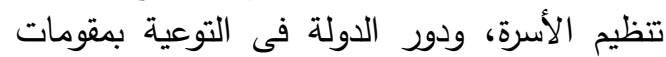
الصحة الإنجابية للنساء.

5- تحديد الفجوة التطبيقية للمبحوثات فيما يتعلق الإبة

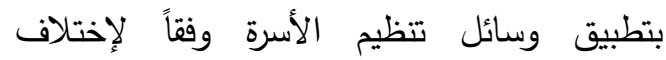
منطقتى الدراسة، ومع تحديد الفجوة ما بين تطبيق لتطبيق المبحوثات لوسائل تتظيم الأسرة ودرجة تفضيلئل الفيلهن

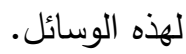


والإجتماعية المستقلة كل على حده، وتشترك هذه الفروض فى صياغة واحدة مفادها: "لا توجد علاقة بين سن المبحوثات عند الزواج

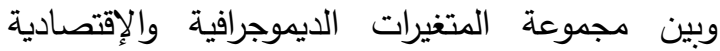
والإجتماعية التالية: المهنة، وعدد سنوات التعليم للمبحوثة، وعدد سنوات تعليم الزوج، وسن المبحوثة عند

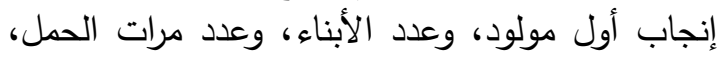

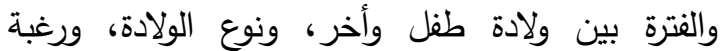
المبحوثة لعدد الأبناء الحالى، ورغبة الزوج لعدئ لعدد الأبناء

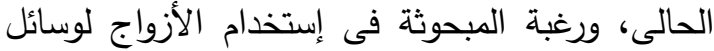

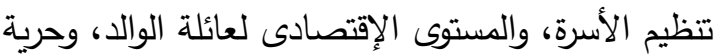

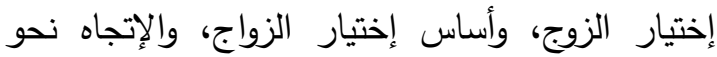

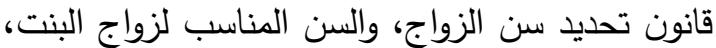

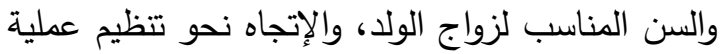
الإنجاب، والرضا عن الإختلاف بين الزوجين للأبناء الإناث، والرضا عن الإختلاف بين الزابلاف الزوجين للأبناء

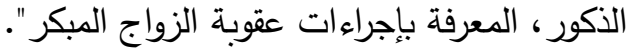
ب- الفروض الإحصائية (22-44): وتختص هذاته الفروض بإختبار العلاقة بين إتجاه المبحوثات نحو

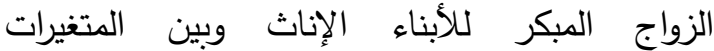
الديموجرافية والإقتصادية والإجتماعية المستقلة كل على الإنى حده، وتشترك هذه الفروض فى صياغة واحدة مفادها:

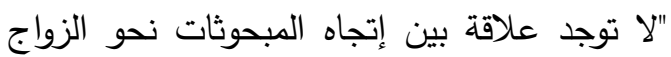

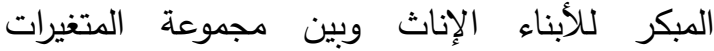
الديموجرافية والإقتصادية والإجتماعية التالية: المهنة،

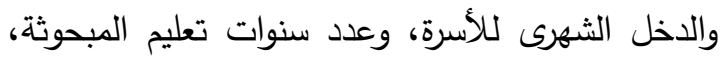
وعدد سنوات تعليم الزوج، وسن المبحوثة الحالى، وسن

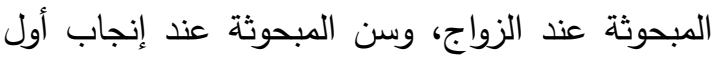

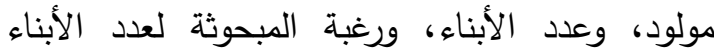

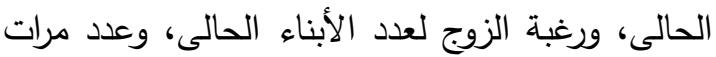

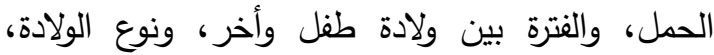

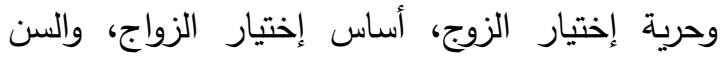
المناسب لزواج البنت، والسن المناسب لزواج الزباج الولد،

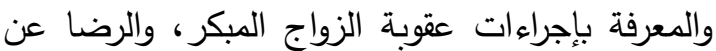

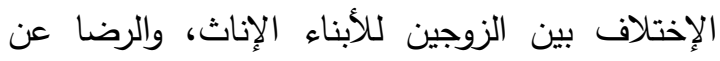
الإختلاف بين الزوجين للأبناء الذكور ، والإتجاه نحو الإناف قانون تحديد سن الزواج، والإتجاه نحو تتظيم عملين الإنية الإنجاب، ودور الدولة فى التوعية بمقومات الصحة

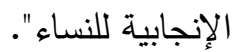

الزواج فى عمر دون 22 سنة أى ما يوافق مرحلة الدراسة الجامعية أو ما قبلها. مفهوم التصادق: هو تسجيل زواج عرفى تم بين

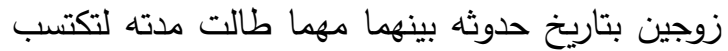
الزوجة حقوقها الشرعية، ووفقاً لإحصاءات 2013 زادت نسبة عقود التصادق بنسبة 13.7\% مقارنة بعام

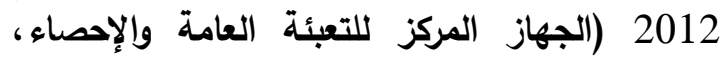

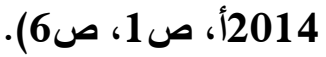

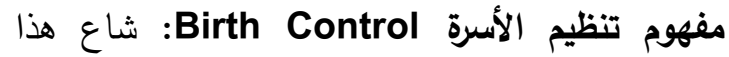

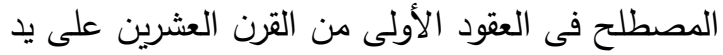
مارجريت سانجر وهى إحدى الرائدات الأمريكيات لنزعة العادين

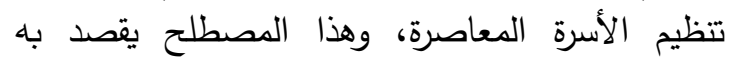
سلوك الزوجين الذى يهدف الى منع الإتصال الجنسى الهیى

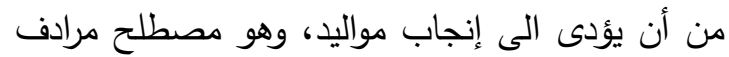
لمنع الحمل contraception ونتظيم الخصوبة Birth Fertility Control Control الأمم المتحدة (العجمى ورزق، 2011) الى الى تتظيم الأسرة على أنه "لكل فرد ولكل زوجين ودني الحق فى إختيار حر ومسئول لعدد أطفالهم والمباعدة بين ولادتهم، وأن يحصلوا على المعلومات وعلى التعليم وعلى الوسائل التى تمكنه من تحقيق ذلك، كما رأى سعدودى التى التى (2008، صائ89) أن تتظيم الأسرة عبارة عن إستعمال

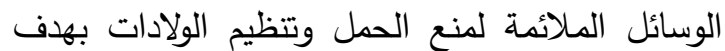

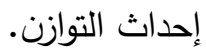
مفهوم منع الحمل contraception Concept: عبارة عن فعل مقصود من جانب الزوجين للحيلولة

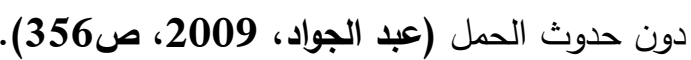
فروض الاراسة: فى ضوض تحديد أهم العوامل المؤثرة على سن زواج

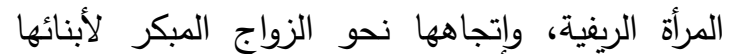

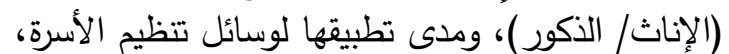

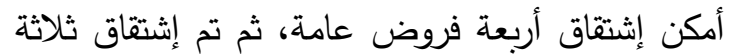
وثمانون فرضاً إحصائياً، وذلك لتحقيق الهدف الثاني الثانى

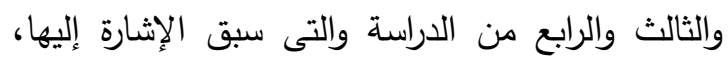
وبيان الفروض الإحصائية فيما يلى:

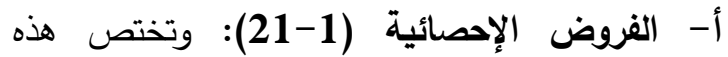
الفروض بإختبار العلاقة بين سن المبحوثات الإية عند الزواج وبين المتغيرات الديموجرافية والإقتصادية لئنات 
منهجية الدراسة وأدواتها

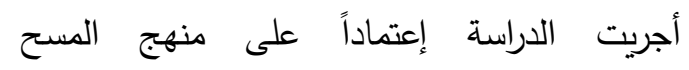
الإجتماعى فى قريتين بمحافظة الثرقية حيث تم إختيار

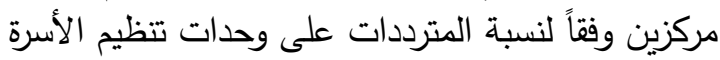

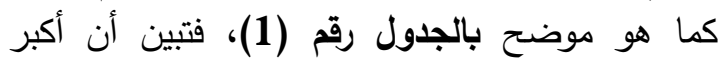

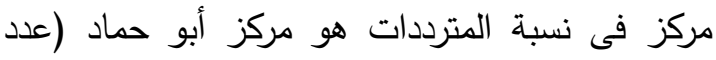

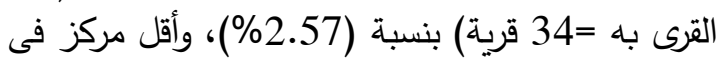

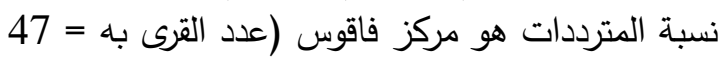

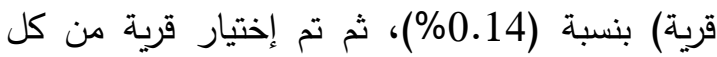
مركز عشوائياً بإستخدام طريقة الكيس المثالى فئل فكانت

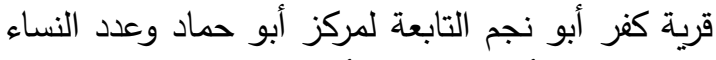

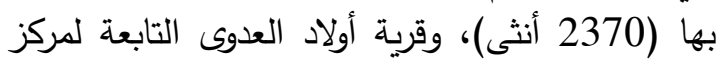

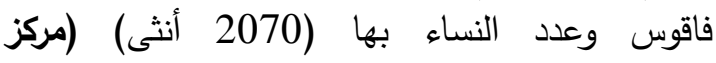
المعلومات ودعم إتخاذ القرار، 2015)، ولتحديد التراء عينة

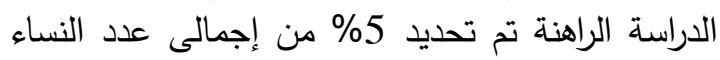

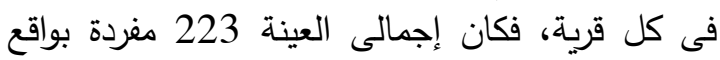

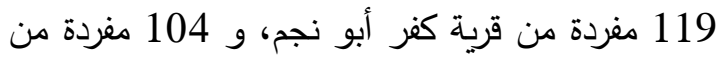
قرية أولاد العدوى، وتم إختيار مفردات العند العينة بطريقة

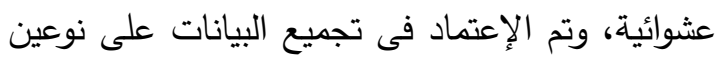

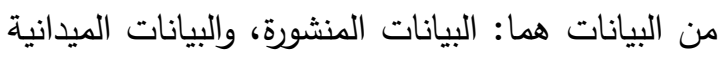

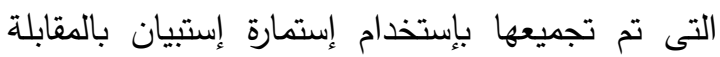

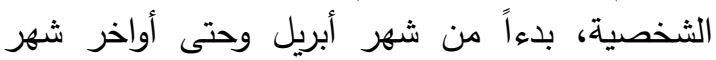
يونيه 2016.

وتم تحليل البيانات بإستخدام عدة أساليب إحصائية هى: 1- التكررات والنسب المئوية.

Cronbach's alpha معامل ألفا كرونباخ النجانة Coefficient 3- المتوسط المرجح ويمكن توضيحه كما فى المعادلة

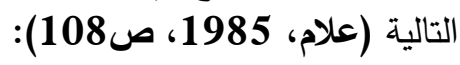

$$
\begin{aligned}
& \bar{x}=\frac{\sum n x}{\sum n}
\end{aligned}
$$

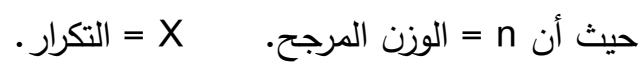

$$
\begin{aligned}
& \text { 4- معامل إرتباط بيرسون. }
\end{aligned}
$$

5- 5عامل التوافق لإختبار العلاقة الإقترانية. 6- حساب الفجوة التطبيقية بإستخدام المعادلة التالية:
ج- الفروض الإحصائية (45-67): وتختص هذه الفروض بإختبار العلاقة بين إتجاه المبحوثات (45) وتخات نحو

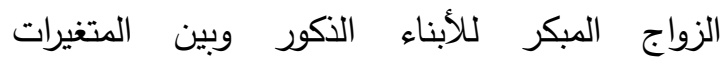

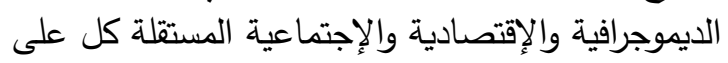
حده، وتشترك هذه الفروض في صياغة الإنهائه واحدة مفادها: "لا توجد علاقة بين إتجاه المبحوثات نحو الزئن الزواج

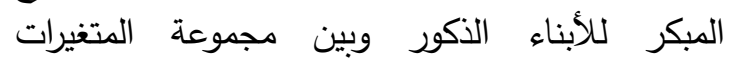

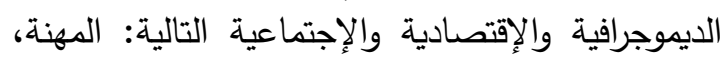

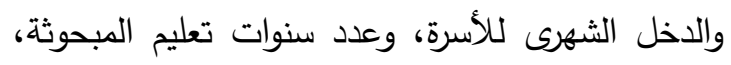

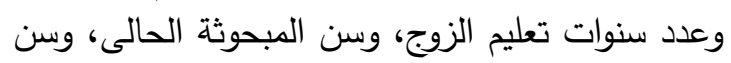

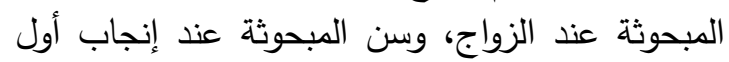

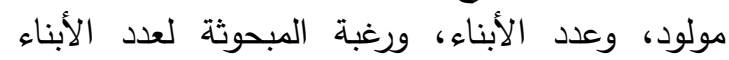

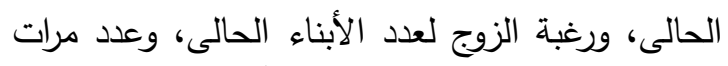

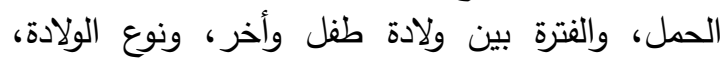

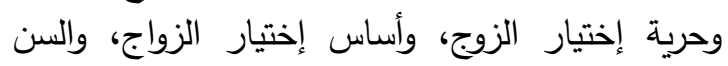

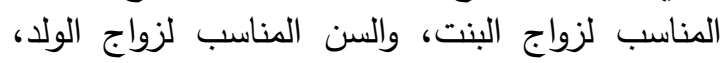

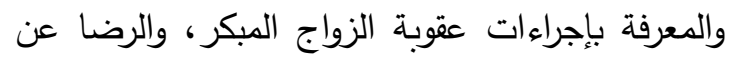

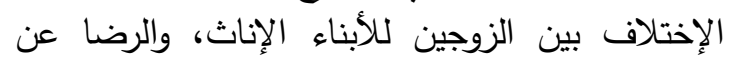
الإختلاف بين الزوجين للأبناء الذكور ، والإتجاه نحون والرضاء قانون تحديد سن الزواج، والإتجاه نحو تتظين لإناء عملية الإنجاه الإنجاب، ودور الدولة في التوعية بمقومات الإنجاه نحونة الصحة الإنجابية للنساء". الإنجاء ودور الإحوض

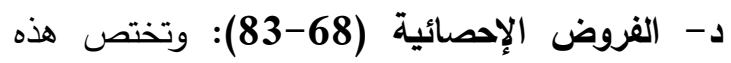
الفروض بإختبار العلاقة بين درجة تطبيق وسائل تنظيم

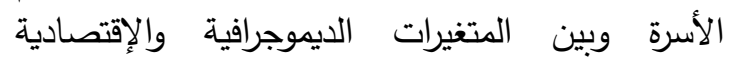

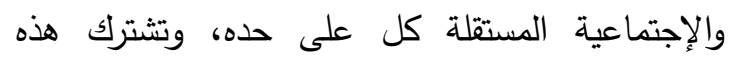
الفروض فى صياغة واحدة مفادها: "لا توجد علاقة بين درجة تطبيق وسائ وسائل تتظيم

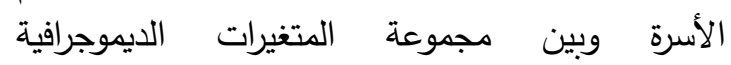
والإقتصادية والإجتماعية التالية: المهنة، والتينة والدخل الثهرى للأسرة، وعدد سنوات تعليم المبحوثة، وعدد

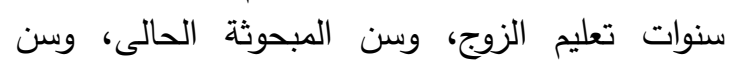

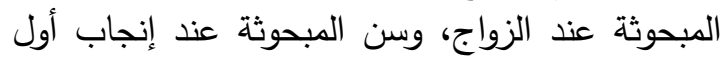

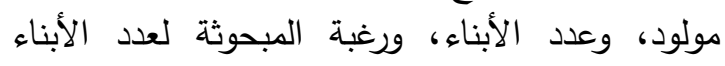

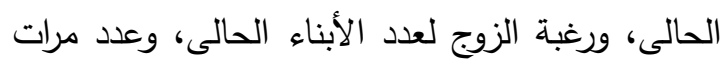

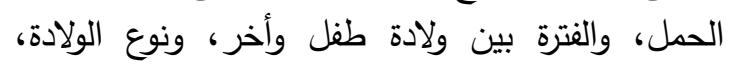

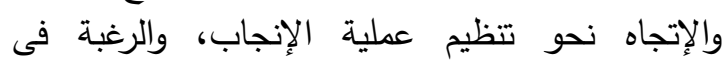

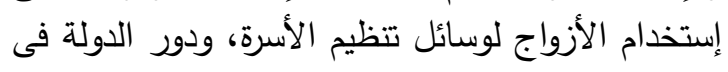
التوعية بمقومات الصحة الإنجابية للنساء". 
الاخل الثهرى للأسرة: عبارة عن جملة الدخل الشهرى للأسرة، وتم قياسه كمتغير كمى بإستخدام الأرقام

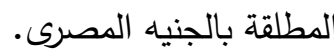
كفاية الاخل الثهرى للأسرة: ويقصد باله مدى كفاية

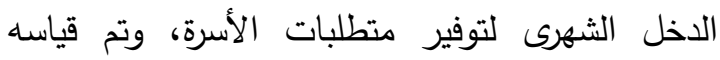
كمتغير رتبى، ورمزت الإستجابات: كافى = 3. 3، كافى

$$
\text { لحد ما = 2، غير كافى وردزت الإنجابات }
$$

سن المبحوثة الحالى: عبارة عن سن المبحوثة المباء وقت

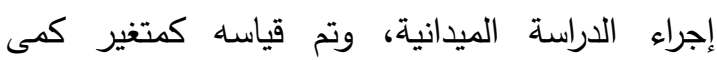
بإستخدام عدد السنوات منذ الميلاد بالأرقام المطلقة.

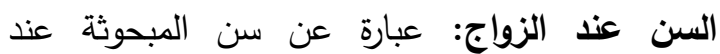
زواجها، وتم قياسه كمتغير كمى بإستخدام عدد السنوات

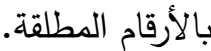
عدد الأبناء: عبارة عن جملة عدد أبناء المبحوثة، وتم قياسه كمتغير كمى بإستخدام الأرقام المطلقة.

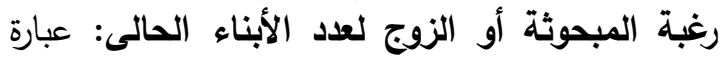

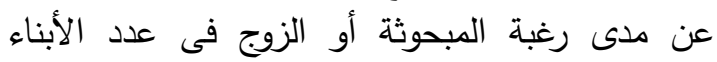

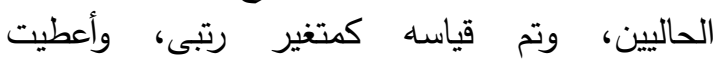
الإستجابات: حسب الرغبة = 3، 3، أكثر من الرغبة

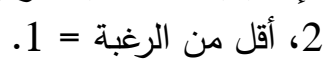
عدد مرات الحمل: عبارة عن عدد الرغة المرات التى حملت

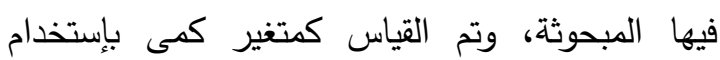
الأرقام المطلقة.

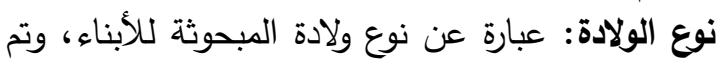

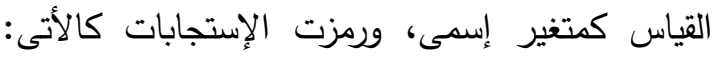

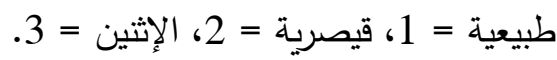
الفترة بين ولادة طفل وأخر : عبارة الأنين عن الفترة الزمنية

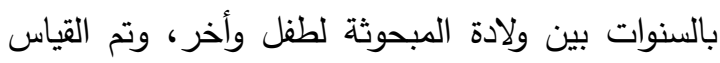
كمتغير كمى بإستخدام الأرقام المطلقة.

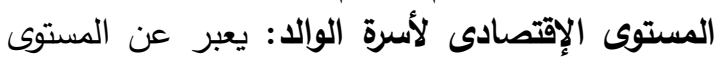

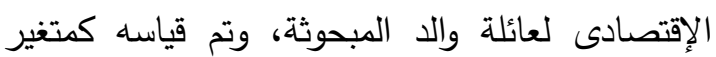

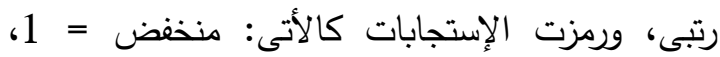

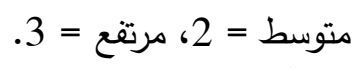
حرية إختيار الزوج: يعبر عن من مدى حتى حرية المبحوثة فى

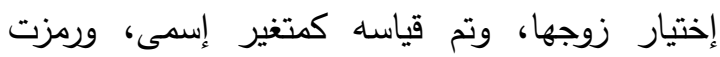

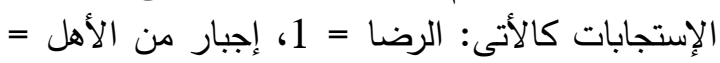

$$
\text { 2، تقليدى = } 3 .
$$

$$
\text { الفجوة التطبيقية = التطبيق فت القرية الأولى - متوسط التطبيق فى القرية الثانية } 100 \text { متوسط التطبيق فى القرية الأولى }
$$

\begin{tabular}{|c|c|c|}
\hline الترتيب & نسبة التردد على الأسرة تنظيم & المركز \\
\hline الأول & 2.57 & 1-مركز أبو حماد. \\
\hline الثانى & 0.472 & 2-أبو كبير • \\
\hline الثالث & 0.444 & 3-مشتول السوق. \\
\hline الرابع & 0.442 & 4-الزقازيق. \\
\hline الخامس & 0.375 & 5-ههيا. \\
\hline السادس & 0.368 & 6-الحسينية. \\
\hline السابع & 0.350 & 7-منيا القـح. \\
\hline التامن & 0.308 & 8-الإبراهيمية. \\
\hline التاسع & 0.284 & 9-بلبيس. \\
\hline العاشر & 0.284 & 10-ديرب نجم. \\
\hline الحادى & 0.261 & 11-أولاد صقر . \\
\hline ع عشر & & \\
\hline عشر & 0.259 & 12-كفرصقر • \\
\hline عشر الثالث & 0.140 & 13-فاقوس. \\
\hline
\end{tabular}

جدول 1. نسبة التردد على وحدات تتظيم الأسرة

المصدر: مركز المعلومات ودعم إتخاذ القرار (2015): "بيان بتنظيم الأسرة والطب الوقائى"، محافظة الشرقية. التعريفات الإجرائية وقياس المتغيرات المهنة: تعبر عما إذا كانت المبحوثة تعمل أم لا، وتم

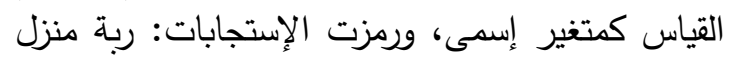

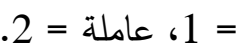
عدد سنوات تعليم المبحوثة أو تعليم الزوج: ويقصد

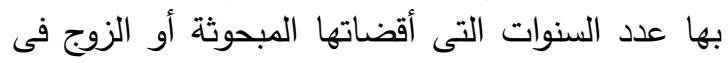
المراحل التعليمية، وتم القياس كمتغير كمى بإستخدام الأرقام المطلقة. 


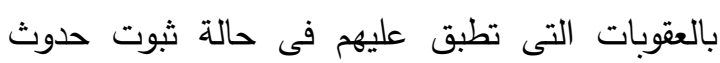

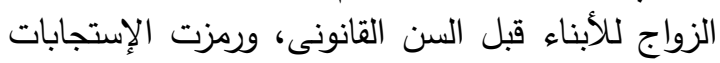

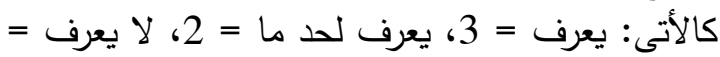

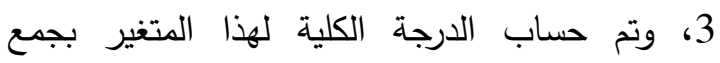
الدرجات التى حصلت عليها كل مبحوثة.

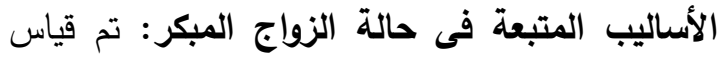

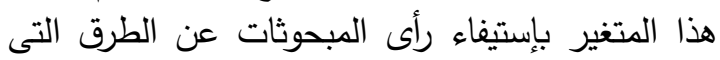

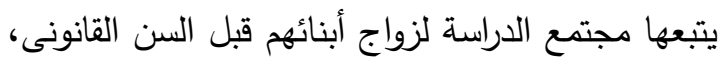

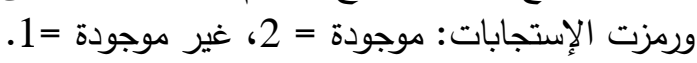
الرضا عن الإختلاف بين الزوجين مودين للأبناء (الإناث أو أو

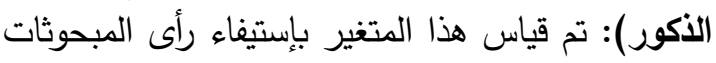

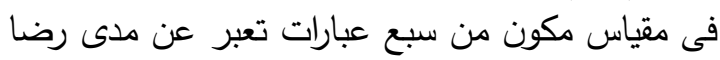

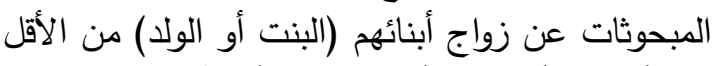

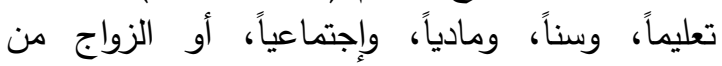

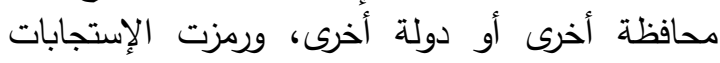

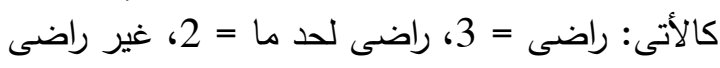

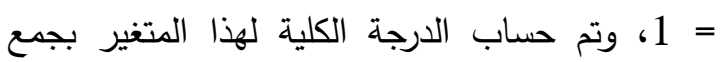
الدرجات التى حصلت عليها كل مبحوثة.

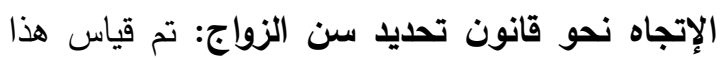

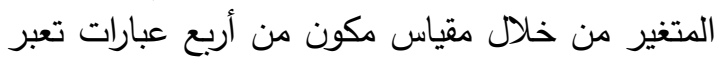

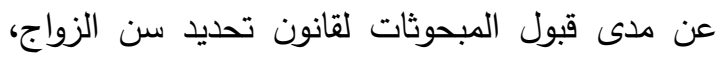
ودرجة ميلهن لعدم وجود قانون يتحكم فى سن الزئن الزواج

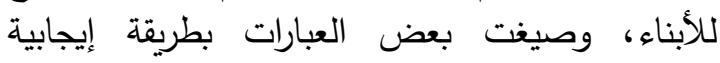

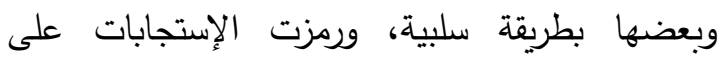

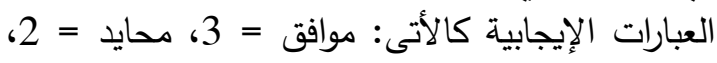
غير موافق = 1 مع عكس الأوزان في فلى حالة العبات العبارات

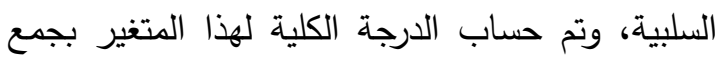
الأدجات التى حصلت عليها كل مبحوثة.

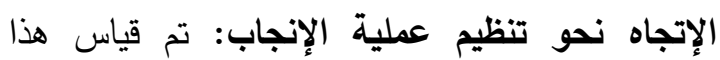

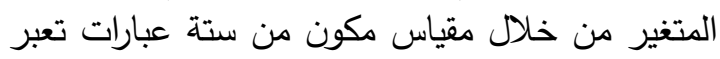

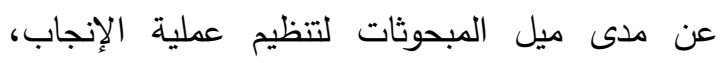

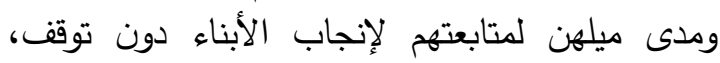

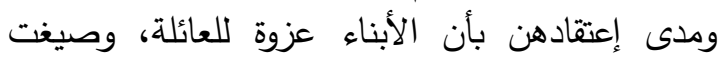

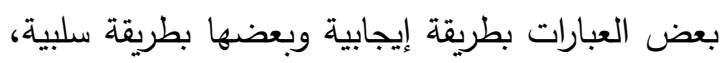

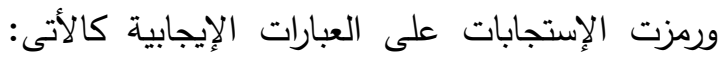

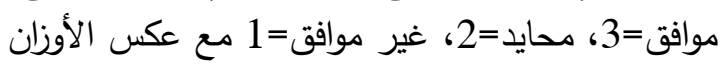
فى حالة العبارات السلبية، وتم حساب الدير الدرجة الكلية

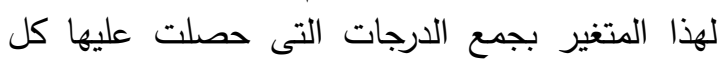

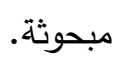

أساس إختيار الزواج: يعبر عن البعد الذى يتم على إلى

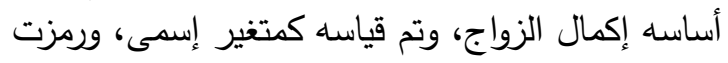

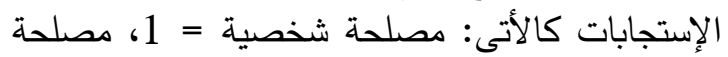
عائلية = 2، الحب = 3، الإتى : القرابة = 4. السن المناسب لزواج البنت أو الولا: يعبر عن السن السن

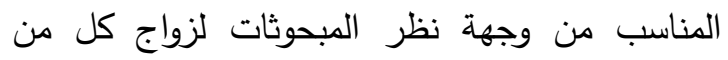

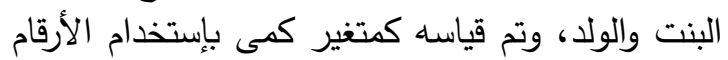

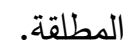

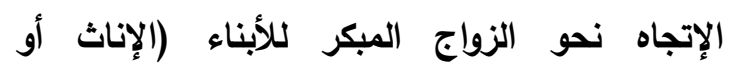
الأكور): تم قياس هذا المتغير من خلاه مقياس مكون

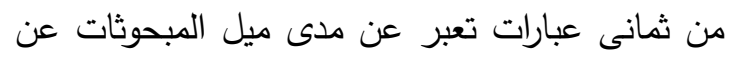

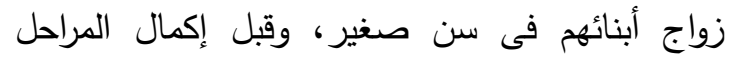

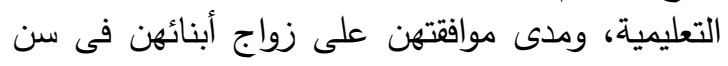

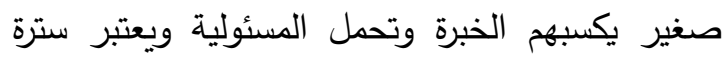
لهم، وتم حساب معامل الثبات لهذا المتغير بإستخدام

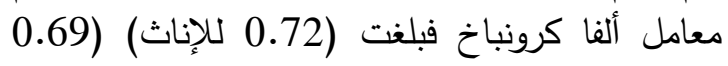
للذكور) وهى درجة ثبات مرتفعة للمقياس، وصيغت

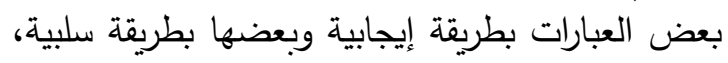
وتم ترميز الإستجابات على العبارات الإيجابية كالأتى

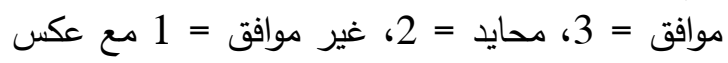
الأوزان فى حالة العبارات السلبية، وتم حساب الدابل الدرجة الكلية لهذا المتغير بجمع الدرجات التى حصلت التئ عليها

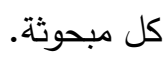
الرغبة فى إستخدام الأزواج لوسائل تنظيم الأسرة: يعبر عن مدى رغبة المبحوثة فى إستخدام أزواجهن

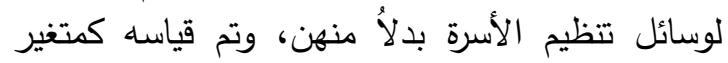

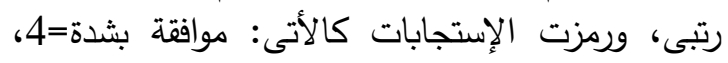
موافقة بشروط = 3، غير موافقة = 2، غير متأكدة = الأسباب التى تدفع الى الزواج المبكر للأبناء: تم

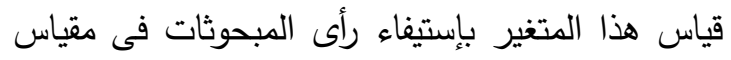

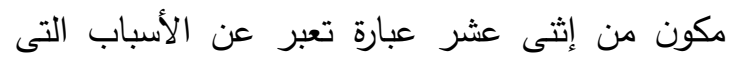

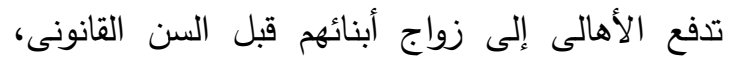

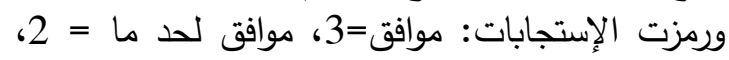

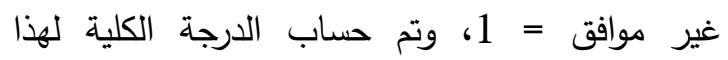

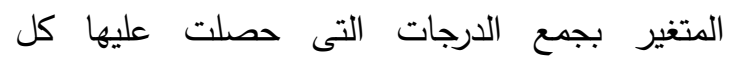

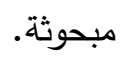
المعرفة بإجراءات عقوبة الزواج المبكر: تم قياس هذاء

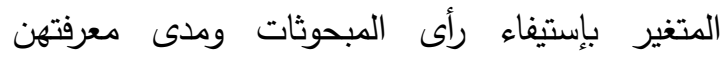


بنسبة 56.1\%، متفقة مع (Singh and) Samara, 1996) حيث أثار أن غالبية المبحوثات بنسبة 74.9 تزوجن فى عمر متوسط، تختلف مع (رنقات

1994

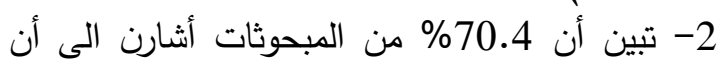

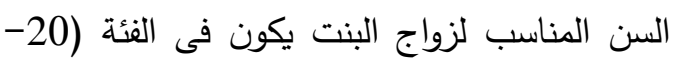

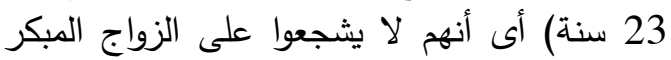

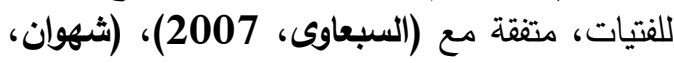
2012)، (القصاص، 2013)، كما أنها وتتفق إنقان هذه النتيجة مع نظرية كنجزلى ديفيز التى ترى أنه

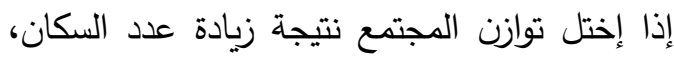

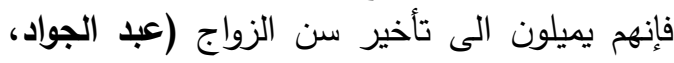

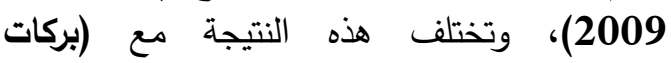
وأخرون، 2003)، الأنصارى، 2014) 2010)،

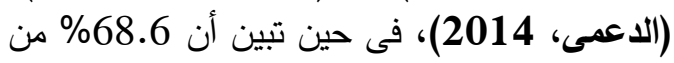
المبحوثات أشارن الى أن السن المناسب لزئ لزواج الولد

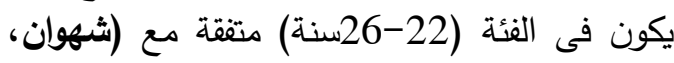

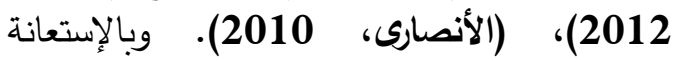
بالبيانات المنشورة الخاصة بمحافظة الثرقية تبين أنها تحتل المركز السادس بين المحافظات من حيث التيث عقود الزواج بمعدل 11.6 عام 2011 (الجهاز

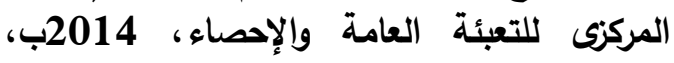
ص66)، كما تبين أن عدد عقود الزواج الرسمية لأقل من 20 سنة بلغ نحو 6801 حالة (الجهاز

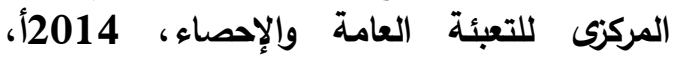

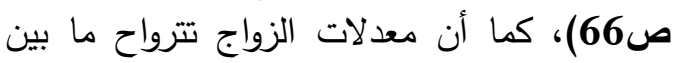

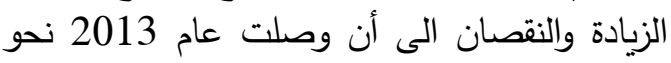

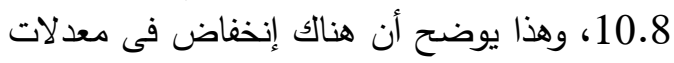
الزواج على المستوى العام (الجهاز المركز للتعبئة

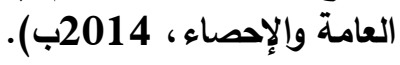
3- تبين أن نحو 43.5\%، و 2014 \%9.8 من الكبحوثات إتجاهين سلبى ومحايد نحو الزواج المبكر الأبنائهن

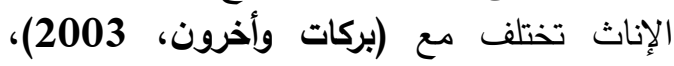
(الدعمى، 2014) حيث أثاروا الى أن أعلى نسبة

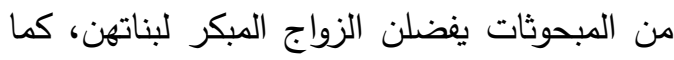

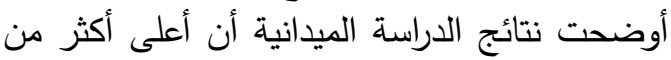

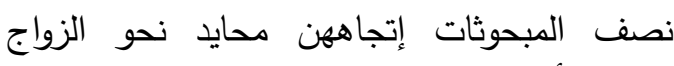
المبكر لأبنائهن الذكور بنسبة 60.5\%
دور الدولة فى التوعية بمقومات الصحة الإنجابية

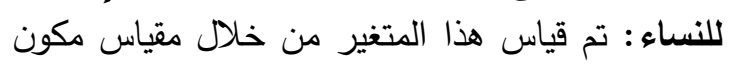

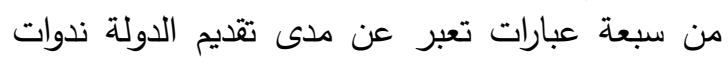

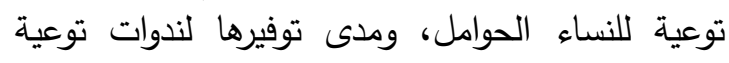

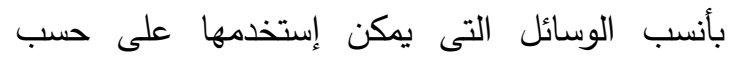
طبيعة كل مرأة، وتوفيرها ندوات توعية بخطر الولادة

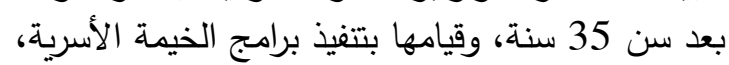

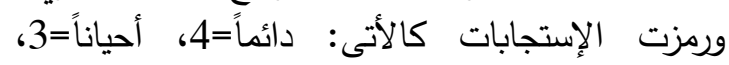

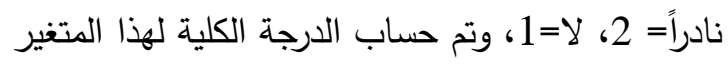
بجمع الدرجات التى حصلت عليها كل مبحوثة.

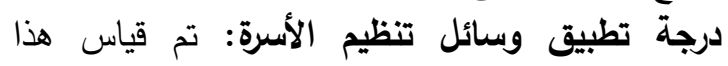

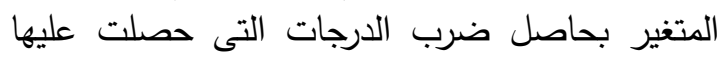

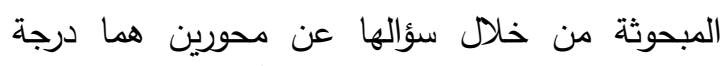
الإستخدام الفعلى لوسائل تنظيم الأسرة (يستخدم =2 2، لا يستخدم=1)، ودرجة الفعالية لهذه الوسائل (فعالة = 2، غير فعالة=1).

خصائص العينة Characteristics of Sample: يشير الجدول رقم (2) إلى أهم خصائص عينة

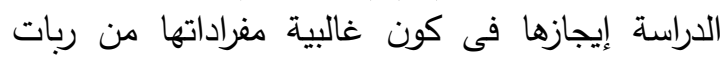

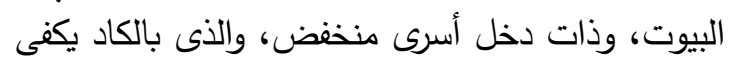

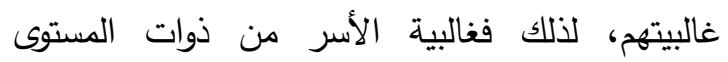
الإقتصادى المتوسط، كما أن غالبيتهم ذات ذات تعليم متوسط حيث أنهم قضوا فى المراحل التعليمية أقل من التن

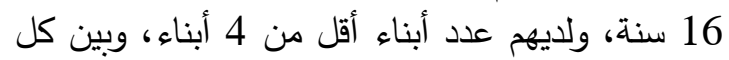

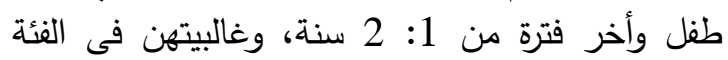
العمرية (31-43 سنة)، وكانت معرفتهن متوسطة فئة

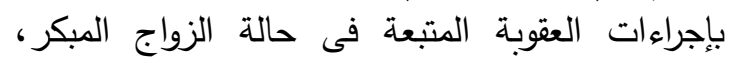
وغالبيتهن أبدين رغبتهن في إستخدام أزواجهن لوسائل الئل تنظيم الأسرة.

توصيف متغيرات الدراسة الميدانية:

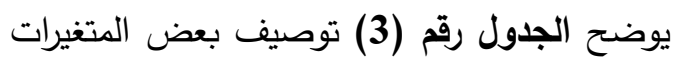

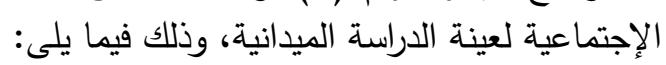

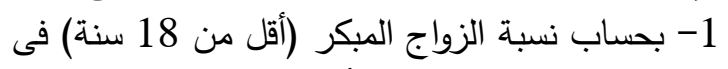

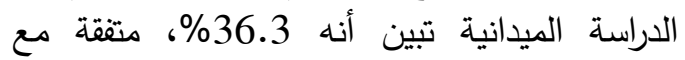
(شوقى وملعاط، 2000) والتى أشارت إلى ألى أن

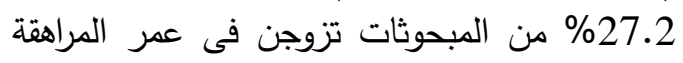

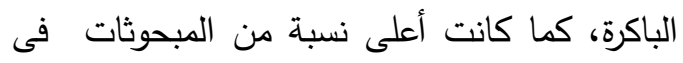
الدراسة الراهنة تزوجن فى عمر (18-24 سنة) 
جدول 2. توصيف الخصائص الديموجرافية والإقتصادية والإجتماعية المدروسة لعينة الدراسة الميدانية

\begin{tabular}{|c|c|c|c|c|c|c|c|}
\hline$\%$ & | العدد (ن = 223) & الفئات & المتفير & $\%$ & |العدد(ن=223) & الفئات & المتغير \\
\hline 22 & 49 & أققل من 10 سنوات & 2-عدد سنوات تعليم & 64.1 & 143 & ربية منزل & \multirow{2}{*}{ 1 1-المهنة. } \\
\hline 73.5 & 164 & من (10: 16 سنة) & \multirow{2}{*}{ | 2-عبحثة. سنوات تعليم } & 35.9 & 80 & عاملة & \\
\hline 4.5 & 10 & |أكتر من 16 سنة & & 91.9 & 205 & فئة دخل أقل من 3334 جنيه & \multirow{3}{*}{ لكاسرة. } \\
\hline 22 & 49 & |أقل من 10 سنوات & \multirow{3}{*}{ | 4-عدوج سنوات تعليم } & 5.8 & 13 & فئة دخل 1334 -6167جنيه) & \\
\hline 74 & 165 & من (10: 16 سنة) & & 2.2 & 5 & فئة دخل أكبر من 6167 جنيه & \\
\hline 4 & 9 & |أكتر من 16 سنة & & 21.5 & 48 & كافى & \multirow{3}{*}{ الشهرى للاسرة. } \\
\hline 30.5 & 68 & فئة عمرية من 30 سنة) & \multirow[t]{3}{*}{ 6-الى السن المبحوثة } & 57 & 127 & كافى لحد ما & \\
\hline 43.5 & 97 & فئة عمرية من 33 سنة) & & 21.5 & 48 & |غير كافى | & \\
\hline 26 & 58 & فئة عمرية من & & 12.1 & 27 & منخفضة & \multirow{3}{*}{ الإلإقتصادى لأسرة } \\
\hline 2.2 & 5 & لا يوجد أبناء & \multirow{4}{*}{ |لعدد الابناء الحالى. } & 76.2 & 170 & متوسطة & \\
\hline 17 & 38 & |أقل من الرغبة & & 11.7 & 26 & مرتفعة & \\
\hline 69.1 & 154 & حسب الرغبة & & 2.2 & 5 & لا يوجد أبناء & \multirow{4}{*}{ 9-عدد الأبناء. } \\
\hline 11.7 & 26 & |أكثر من الرغبة & & 58.7 & 131 & أقل من (4 أبناء) & \\
\hline 2.2 & 5 & لا يوجد أبناء & \multirow{4}{*}{ لعدد الابناء الحالى الزي. } & 36.8 & 82 & من (4: 6 أبناء) & \\
\hline 14.3 & 32 & |أقل من الرغبة & & 2.2 & 5 & أكبر من (6 أبناء) & \\
\hline 72.6 & 162 & حسب الرغبة & & 12.6 & 28 & واحدم وجود ابناء أو ابن & \multirow{4}{*}{ ولادة طفل وأخر . } \\
\hline 10.8 & 24 & |أكثر من الرغبة & & 59.2 & 132 & عدد (1: 2سنة) & \\
\hline 2.2 & 5 & عدم الحمل & \multirow[t]{4}{*}{ 12-نوع الولادة. } & 26.9 & 60 & عدد (3: 4 سنة) & \\
\hline 57.4 & 128 & طبيعية & & 1.3 & 3 & عدد (5: 6سنة) & \\
\hline 18.4 & 41 & قيصرية & & 8.5 & 19 & منخفضة (4-6درجة) & \multirow{7}{*}{ 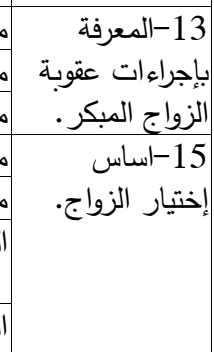 } \\
\hline 22 & 49 & |الإثنين & & 48 & 107 & متوسطة (7-9درجة) & \\
\hline 53.8 & 120 & الرضا & \multirow{3}{*}{ |الزوج. 14 اختية اختيار } & 43.5 & 97 & مرتفعة(10-12درجة) & \\
\hline 5.8 & 13 & اجبار من الاهل & & 5.4 & 12 & مصلحة شخصية & \\
\hline 40.4 & 90 & تقليدى & & 16.6 & 37 & مصلحة عائلية & \\
\hline 9.9 & 22 & |رضا منخفض & \multirow{3}{*}{ |الإختلاف بين الزبن } & 38.6 & 86 & |الحب & \\
\hline 55.2 & 123 & |رضا متوسطة & & 39.5 & 88 & |القرابة & \\
\hline 35 & 78 & رضا مرتفع & & 30.5 & 68 & |غير متاكدة & \multirow{4}{*}{ الاسائل التظيم الازواج } \\
\hline 17.9 & 40 & رضا منخفضة (711 ادرجة) & \multirow{3}{*}{ 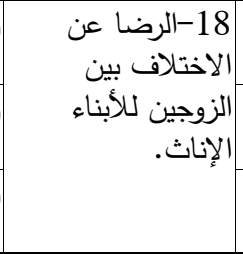 } & 7.6 & 17 & غير موافقة & \\
\hline 46.6 & 104 & |رضا متوسطة & & 6.3 & 14 & موافقة بشروط & \\
\hline 35.4 & 79 & رضا مرتفع & & 55.6 & 124 & موافقة جدا & \\
\hline
\end{tabular}


جدول 3. توصيف المتغيرات الإجتماعية للدراسة الميدانية.

\begin{tabular}{|c|c|c|c|c|c|c|c|}
\hline$\%$ & العدد (ن= 3 & الفئــات & المتغير & $\%$ & | العدد (ن= 223) | & الفئــات & المتغير \\
\hline 15.7 & 35 & سن أقل من 20سنة & \multirow{3}{*}{ لزاج البنت. البناسب } & 36.3 & 81 & |أقل من 18 سنة & \multirow{3}{*}{ 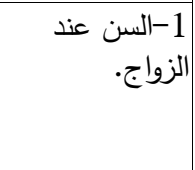 } \\
\hline 70.4 & 157 & سنة من (20: 23 & & 56.1 & 125 & من (18: 24 سنة) & \\
\hline 13.9 & 31 & سن أكبر من 23 سنة & & 7.6 & 17 & |أكثر من 24 سنة & \\
\hline 43.5 & 97 & منخفض) (8-13 & \multirow{3}{*}{ الزالزات المبكر للأبناء } & 11.2 & 25 & سن من أقل من 22سنة & \multirow{3}{*}{ 3 الزواج الولد. المناسب } \\
\hline 49.8 & 111 & متوسط) (14-19 & & 68.6 & 153 & سن من (22: 26 سنة) & \\
\hline 6.7 & 15 & مرتقع (20-24 درجة) & & 20.2 & 45 & سن أكبر من 26 سنة & \\
\hline 6.3 & 14 & |اتجاه سلبى (4- & \multirow{3}{*}{ 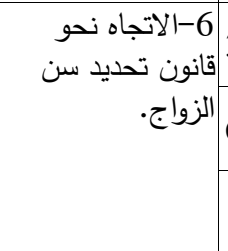 } & 32.3 & 72 & سلبى (8-13 درجة) & \multirow{3}{*}{ اللأزبناء الذكور . المبكر } \\
\hline 70.4 & 157 & 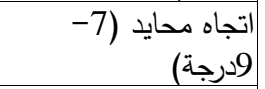 & & 60.5 & 135 & محايد (14-19 درجة) & \\
\hline 23.3 & 52 & 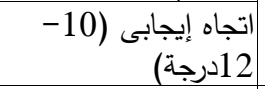 & & 7.2 & 16 & إيجابى (20-24 درجة) & \\
\hline 49.8 & 111 & |تفضيل منخفض(9 13 & \multirow[t]{3}{*}{ | 8 -تظضيم الأسرة. وسائل } & 5.8 & 13 & اتجاه سلبى (6-9درجة) & \multirow{3}{*}{ الانجياب. } \\
\hline 38.6 & 86 & تفضيل متوسط(14 18 درجة) & & 75.8 & 169 & |تجاه محايد (10-14 & \\
\hline 11.7 & 26 & |تفضيل مرتفع(19- & & 18.4 & 41 & \begin{tabular}{r|r|r|} 
18 إيجابى (15) \\
\\
\end{tabular} & \\
\hline 10.8 & 24 & |توعية منخفضة(7) & |التوعية 10 بدور الدولة فحمات & 49.3 & 110 & تطبيق منخفض (12 & \multirow{3}{*}{ 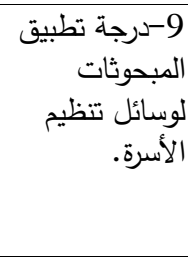 } \\
\hline 56.1 & 125 & |توعية متوسطة(14- 14 (14رجة) & \multirow[t]{2}{*}{ |للنساء. } & 35 & 78 & 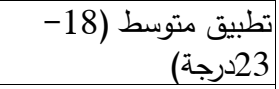 & \\
\hline 33.2 & 74 & توعية كبيرة (22 (22- & & 15.7 & 35 & 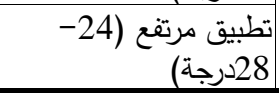 & \\
\hline
\end{tabular}

5- تبين أن أكثر من نصف المبحوثات 56.1\% أثارن الى أن دور الدين الدولة فى التوعية بمقومات الصحة الإنجابية الأمنة متوسط.

\section{النتائج والمناقشة}

أولاً: أسباب الزواج المبكر للأبناء، والأساليب المتبعة

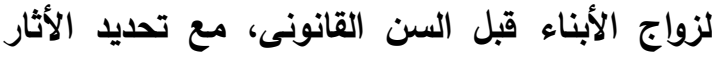
المترتبة على حدوثه الائه

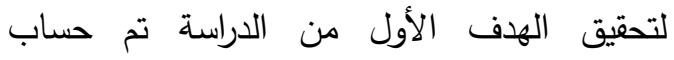

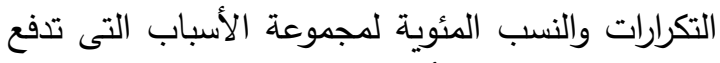

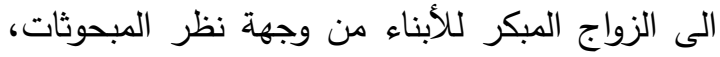

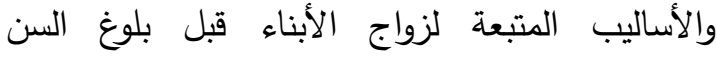

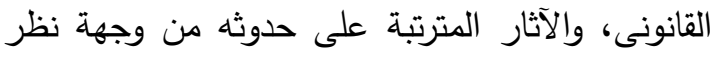

4- تبين أن 75.8\% من المبحوثات ذو إتجاه محايد نحو تنظيم عملية الإنجاب متفقة مع العي (العموش، 2001)، (العجمى ورزق، 2011)، وتئق هذه الإن النتيجة مع نظرية كنجزلى ديفيز التى ترى أنه إذبا

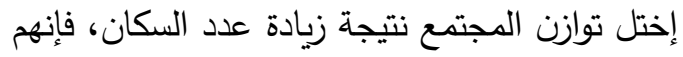

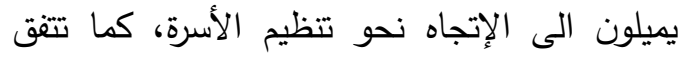

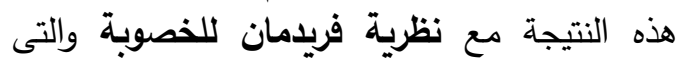

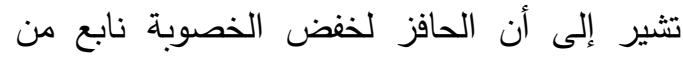
إتجاهات الأسر وإيمانهم بمميزات الأسرة الصغيرة (عبد الجواد، 2009)، فى حين تبين أن أعلى التى نسبة من المبحوثات درجة تفضيلهن وتطبيقهن

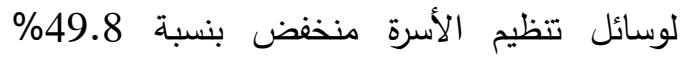
للتضضيل، و49.3\% للتطبيق. 
2010)، كثرة المال سبب في الزواج المبكر للأبناء

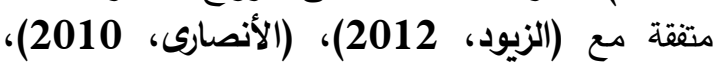
مساعدة وخدمة الأسرة فى العمل، الإقتخار أمام أهل

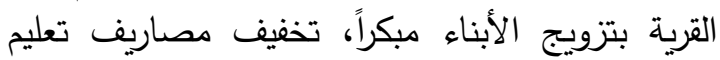

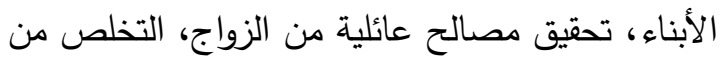

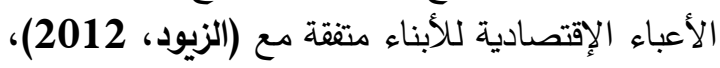

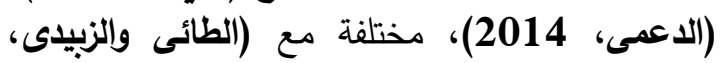

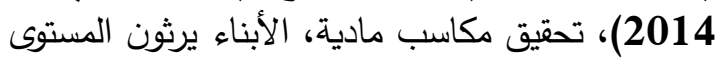

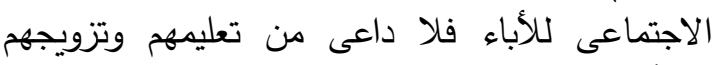
مبكراً (الأنصارى، 2010).
المبحوثات، وترتيبها وفقاً لأهميتها بإستخدام المتوسط

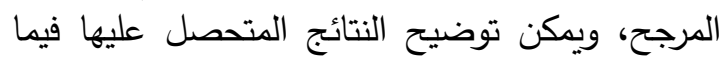

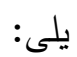

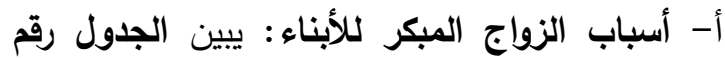

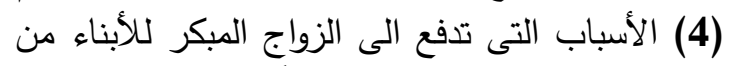

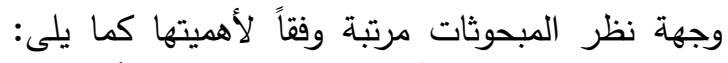

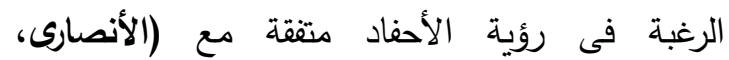

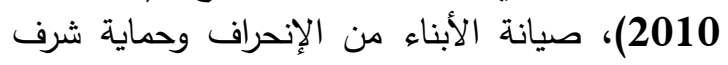

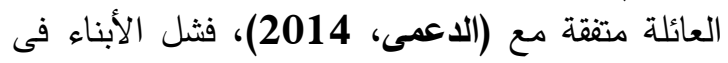
الدراسة، الرغبة فى زيادة نسل العائلة (الأنصارى،

جدول 4. أسباب الزواج المبكر للأبناء وترتيبها وفقاً للمتوسط المرجح

\begin{tabular}{|c|c|c|c|c|c|c|c|c|}
\hline \multirow{3}{*}{ الترتيب } & \multirow{3}{*}{ | المرجوسط } & \multicolumn{6}{|c|}{ أسباب الزواج المبكر للأبناء } & \multirow{3}{*}{ الأسباب } \\
\hline & & \multicolumn{2}{|c|}{ غير موافق } & \multicolumn{2}{|c|}{ لحد ما } & \multicolumn{2}{|c|}{ موافق } & \\
\hline & & $\%$ & & $\%$ & العدد & $\%$ & 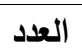 & \\
\hline الأول & 84.5 & 11.2 & 25 & 50.2 & 112 & 38.6 & 86 & 1-الرغبة فى رؤية الأحفاد. \\
\hline 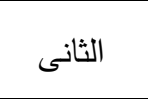 & 83.5 & 11.2 & 25 & 52.9 & 118 & 35.9 & 80 & 2- العائلة. صيانة الأبناء من الإنحراف وحماية شرف \\
\hline الثالث & 82.8 & 13.5 & 30 & 50.2 & 112 & 36.3 & 81 & 3-فثل الأبناء فى الدراسة. \\
\hline الرابع & 78 & 17.5 & 39 & 55.2 & 123 & 27.4 & 61 & 4-الرغبة فى زيادة نسل العائلة. \\
\hline 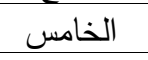 & 77.8 & 22 & 49 & 46.6 & 104 & 31.4 & 70 & 5-كثرة المال سبب فى الزواج المبكر للأبناء. \\
\hline السادس & 77 & 12.6 & 28 & 67.7 & 151 & 19.7 & 44 & 6-مساعدة وخدمة الأسرة فى العمل. \\
\hline 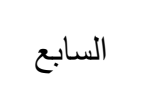 & 73.2 & 29.1 & 65 & 44.8 & 100 & 26 & 58 & 7 7-الإفتخار أمام أهل القرية بتزويج الأبناء \\
\hline 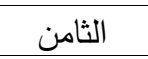 & 72.7 & 31.8 & 71 & 40.8 & 91 & 27.4 & 61 & 8-تخفيف مصاربف تعليم الأبناء. \\
\hline 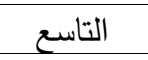 & 71.7 & 31.4 & 70 & 44.4 & 99 & 24.2 & 54 & 9-تحقيق مصالح عائلية من الزواج. \\
\hline العاشر & 69.3 & 31.4 & 70 & 50.7 & 113 & 17.9 & 40 & 10-التخلص من الأعباء الإقتصادية للأبناء. \\
\hline 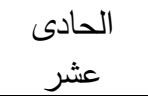 & 68.8 & 37.7 & 84 & 39.5 & 88 & 22.9 & 51 & 11-تحقيق مكاسب مادية. \\
\hline 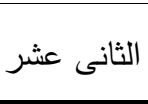 & 66 & 42.6 & 95 & 37.2 & 83 & 20.2 & 45 & 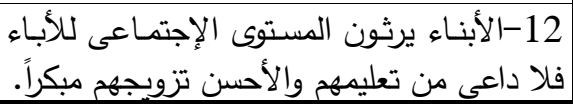 \\
\hline
\end{tabular}

لسفر الزوج للخارج والزواج من أجنبية، كتابة شهادة

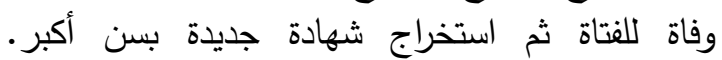

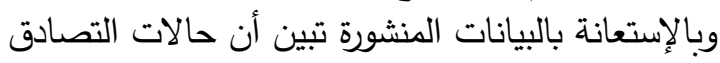

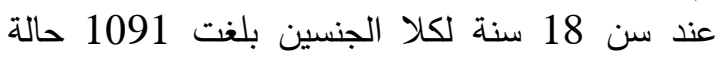

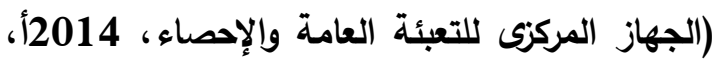

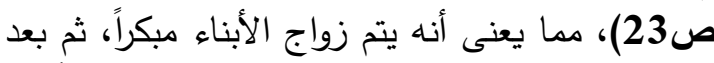
ذلك يتم الإتجاه إلى توثيق هذه العقود العرفية رسمياً.
ب- الأساليب المتبعة لزواج الأبناء قبل السن

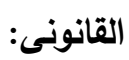

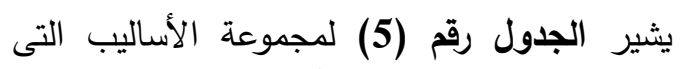

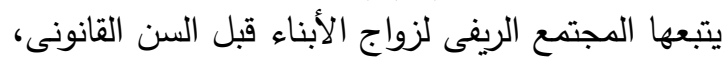

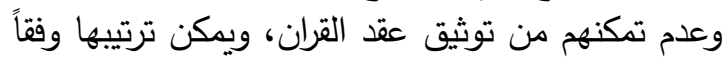

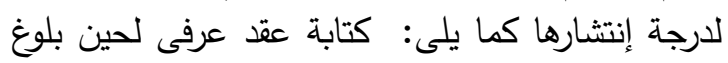

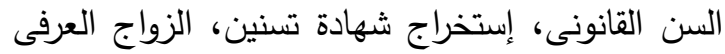


جدول 5. الأساليب المتبعة لزواج الأبناء قبل السن القانونى

\begin{tabular}{|c|c|c|c|c|c|c|}
\hline \multirow{2}{*}{ 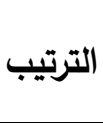 } & \multirow{2}{*}{ |المتوسط } & \multicolumn{2}{|c|}{ 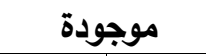 } & \multicolumn{2}{|c|}{ غير موجود } & \multirow{2}{*}{ 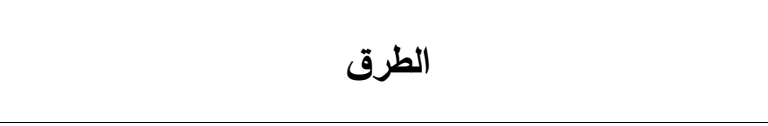 } \\
\hline & & $\%$ & 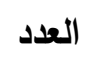 & $\%$ & 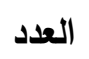 & \\
\hline 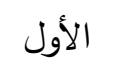 & 138 & 85.7 & 191 & 14.3 & 32 & 1-كتابة عقد عرفى لحين بلوغ السن القانونى. \\
\hline الثانى & 122.3 & 64.6 & 144 & 35.4 & 79 & 2- إستخراج شهادة تسنين. \\
\hline 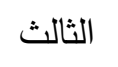 & 106 & 42.6 & 95 & 57.4 & 128 & 3-الزواج العرفى لسفر الزوج للخارج والزواج من أجنبية. \\
\hline 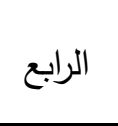 & 92 & 23.8 & 53 & 76.2 & 170 & 4-كتابة شهادة وفاة لفتاة ثم استخراج شهادة جديدة \\
\hline
\end{tabular}

سن النساء إلى أن يصل أقصاه فى الفئة العمرية

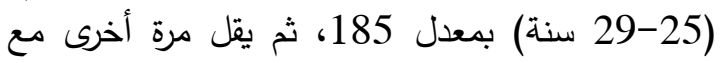

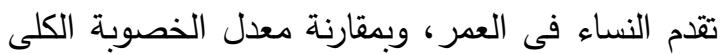

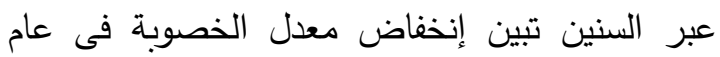

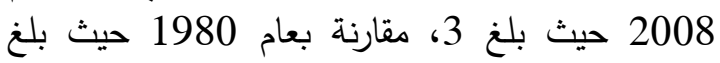

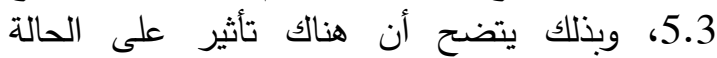
الصحية للنساء. 2- الآثار الإجتماعية: الحرمان من فرص التعليم متفقة مع (الزيود، 2012)، (الاجتماعة 2014)، (الثهوان، 2012)،

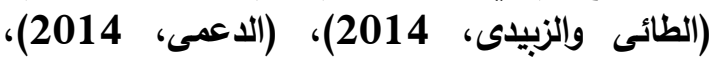
والزيادة السكانية نتيجة زيادة الإنجاب، والحرمان من الإنان

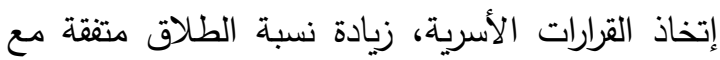

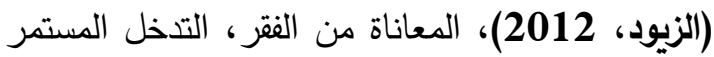

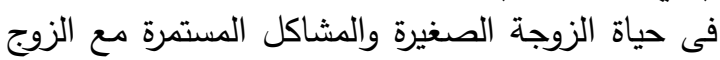

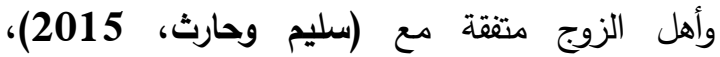
والحرمان من تحديد عدد الأبناء.

3- الآثار النفسية: إضطراب المشاعر والإنفعالات

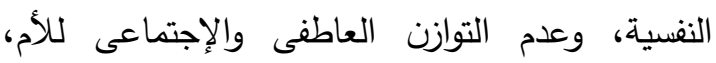

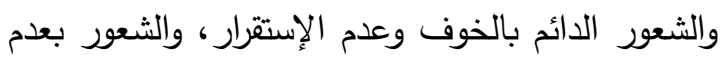

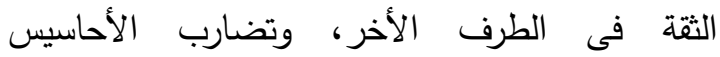
والعواطف فالحب والكراهية لنفس الثخص، والثران الثعور بالضيق والإنطواء.

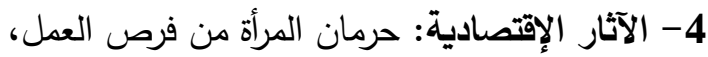

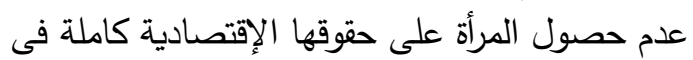
حالة الطلاق، تبعية المرأة للرجل إقتصادياً.
ج- الأثار المترتبة على حدوث الزواج المبكر من

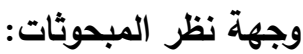
يثير الجدول رقم (6) إلى مجموعة الآثار المترتبة

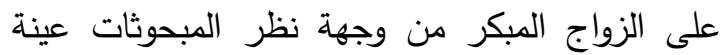

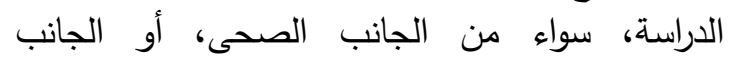

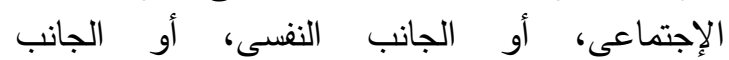
الإقتصادى، ويمكن سرد ذلك وفقاً لدرجة أهميتها داخل الإنل كل مجموعة فيما يلى: الإنى 1- الآثار الصحية: سوء الحالة الصحية للأم متفقة

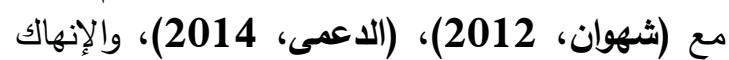

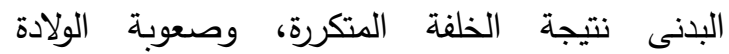

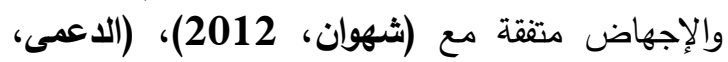

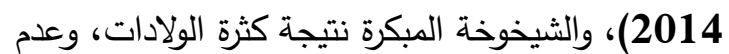
تلقى التغذية المناسبة وإكمال النمو الجسدى للأم نتيجة

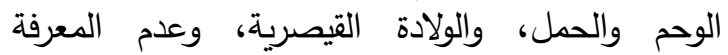

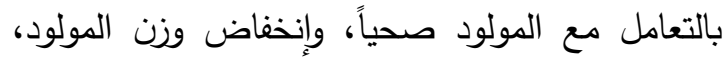

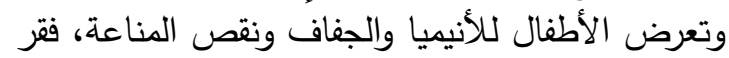
الدم وآلام العظام للأم، زيادة التعرض لحمى التعى النفاس،

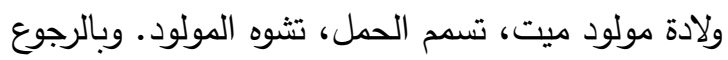
إلى البيانات المنشورة (الجهاز المركز للتعبئة العامة

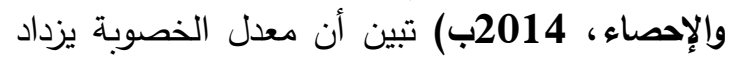

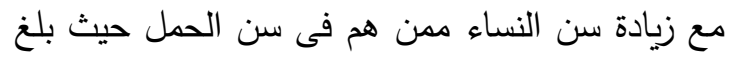

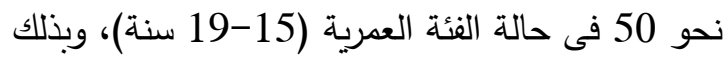

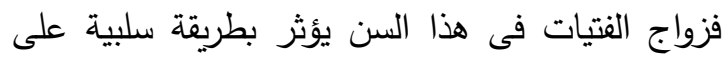
صحة الأم، ويستمر هذا المعدل فى الزيادة مع إرتفاع لطرئ سلئ 
جدول 6. الأثار المترتبة على الزواج الدبكر من وجهة نظر المبحوثات وترتيبها وفقاً للمتوسط المرجح بعينة

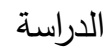

\begin{tabular}{|c|c|c|c|c|c|c|c|c|}
\hline \multirow{2}{*}{ الترتيب } & \multirow{2}{*}{ المترجح } & \multicolumn{2}{|c|}{ غير موافق - افق } & \multicolumn{2}{|c|}{ لحذ ما } & \multicolumn{2}{|c|}{ موافق } & \multirow{2}{*}{ الآثار } \\
\hline & & $\%$ & عدد & $\%$ & عدد & $\%$ & عدد & \\
\hline & & & & & & & & أول أولاً: الآثار الصحية: \\
\hline الأول & 102.2 & 1.8 & 4 & 21.5 & 48 & 76.7 & 171 & 1 - ستحة الخففة الدالة الصحية للأم والإنهاك البدنى \\
\hline الثاني & 101.7 & 4 & 9 & 18.4 & 41 & 77.6 & 173 & 2-صعوبة الولادة والإجهاض. \\
\hline الثالث & 94.5 & 13.9 & 31 & 17.9 & 40 & 68.2 & 152 & 3-الثيخوخة المبكرة نتيجة كثرة الولادات. \\
\hline الرابع & 94.2 & 9.9 & 22 & 26.9 & 60 & 63.2 & 141 & 4-عدم تلقىى التخذية المناسبة وإكمال النمو \\
\hline الخامس & 91.8 & 6.7 & 15 & 39.5 & 88 & 53.8 & 120 & 5- الولادة القيصرية. \\
\hline السادس & 91.5 & 9 & 20 & 35.9 & 80 & 55.2 & 123 & 6- عدم المعرفة بآلتّعامل مع المولود صحياً. \\
\hline السابع & 90.5 & 10.8 & 24 & 35 & 78 & 54.3 & 121 & 7-إنخفاض وزن المولود. \\
\hline الثامن & 89.7 & 15.2 & 34 & 28.3 & 63 & 56.5 & 126 & 8-تعرض الأطفال للأنيميا والجفاف ونقص \\
\hline 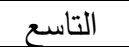 & 89.3 & 18.4 & 41 & 22.9 & 51 & 58.7 & 131 & 9-فقر الدم وآلام العظام للأم. \\
\hline 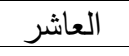 & 88.5 & 11.2 & 25 & 39.5 & 88 & 49.3 & 110 & 10-زيادة التعرض لحمى النفاس. \\
\hline 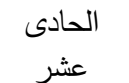 & 87.8 & 14.3 & 32 & 35 & 78 & 50.7 & 113 & \\
\hline 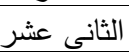 & 87.5 & 11.7 & 26 & 41.3 & 92 & 47.1 & 105 & 12 12-تسمم الحمل. \\
\hline الثاتث عشر & 80.8 & 24.2 & 54 & 34.1 & 76 & 41.7 & 93 & 13-تشوه المولود. \\
\hline & & & & & & & & ثانياً: الآثار الإجتماعية: \\
\hline الأول & 95.2 & 7.6 & 17 & 28.7 & 64 & 63.7 & 142 & 1-الحرمان من فرص "التعليم. \\
\hline الثانى & 92 & 13 & 29 & 26.5 & 59 & 60.5 & 135 & 2- الزبادة السكانية نتيجة زيادة الإنجاب \\
\hline 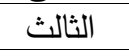 & 90.7 & 8.1 & 18 & 39.9 & 89 & 52 & 116 & 3-الحرمان من إتخاذ القرارات الأسرية. \\
\hline 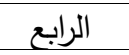 & 90.3 & 9.9 & 22 & 37.2 & 83 & 52.9 & 118 & 4-زيادة نسبة الطلاق. \\
\hline 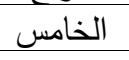 & 89 & 13.5 & 30 & 33.6 & 75 & 52.9 & 118 & 5- المعاناة من الفقر . \\
\hline 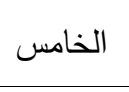 & 89 & 15.2 & 34 & 30 & 67 & 54.7 & 122 & 6- التشاكل الدستمرة مع الزئ حياة الزول الزوة الصغيرة \\
\hline 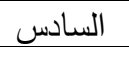 & 87.3 & 16.1 & 36 & 32.7 & 73 & 51.1 & 114 & 7-الحرمان من تحديد عدد الآبناء. \\
\hline & & & & & & & & ثالثاً: الآثار النفسية: \\
\hline الأول & 91.2 & 13.9 & 31 & 26.9 & 60 & 59.2 & 132 & 1-إضطراب الششاعر والإنغعالات النفسية. \\
\hline 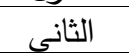 & 90 & 15.7 & 35 & 26.5 & 59 & 57.8 & 129 & 2-عدم التوازن العاطفى والإجتماعى للأم. \\
\hline الثالث & 89.8 & 11.2 & 25 & 35.9 & 80 & 52.9 & 118 & 3-الشعور الدائم بالخوف وعدم الإستقترار. \\
\hline 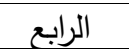 & 89.7 & 14.8 & 33 & 29.1 & 65 & 56.1 & 125 & 4-الشعور بعدم الثثة فى الطرف الأخر. \\
\hline 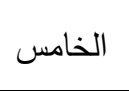 & 89 & 13.5 & 30 & 33.6 & 75 & 52.9 & 118 & 5-تضاربة النفس الشخصيس. والعواطف فالحب \\
\hline السادس & 88.7 & 13.5 & 30 & 34.5 & 77 & 52 & 116 & 6-الشعور بالضيق والإنطواء. \\
\hline & & & & & & & & رابعاً: الآثار الإقتصادية: \\
\hline الأول & 95 & 8.5 & 19 & 27.4 & 61 & 64.1 & 143 & 1-حرمان المرأة من فرص العمل. \\
\hline الثانى & 93.7 & 12.1 & 27 & 23.8 & 53 & 64.1 & 143 & كاملة فدم حصولة الطلاقرة على حقوقها الإقتصادية \\
\hline الثالث & 91.3 & 13.5 & 30 & 27.4 & 61 & 59.2 & 132 & 3-تبعية المرأة للرجل إقتصادياً. \\
\hline
\end{tabular}




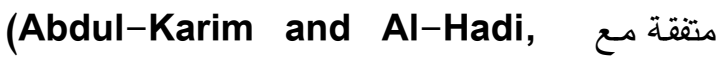
(2005، الرضـا عن الإختلاف بين الزوجين للأبناء

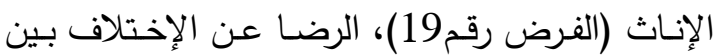

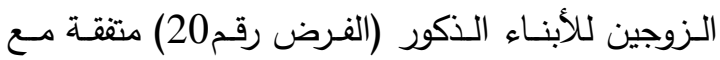
نظرية المعيار والتى تثير الى أنه يجب أن أن يكون هناك الك

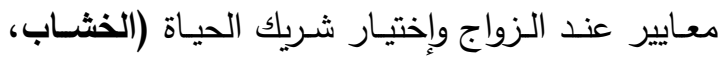

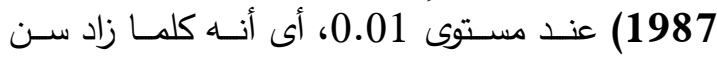

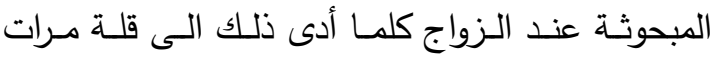

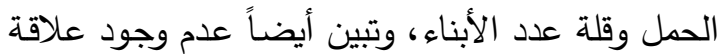
معنوية بين سن المبحوثات عند الزواج وبين متغيرات الإناء

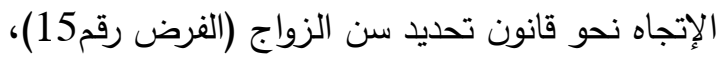

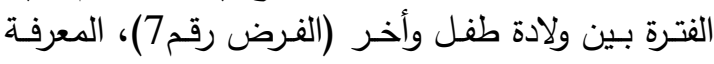
بإجراءات عقوبة الزواج المبكر (الفرض رقم 21 21).

ب- العلاقات الإقترانية بين سن المبحوثات عند الزواج وبين المتغيرات الديموجرافية، والإقتصادية، والإجتماعية المدروسة ذات الطبيعة الإسمية: يشير الجدول رقم (8) إلى وجود علاقة توافقية الإنية موجبة بين سن المبحوثات عند الزواج وبين متغيرات:

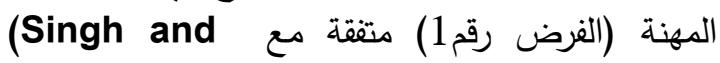

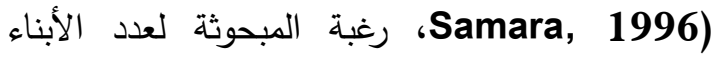

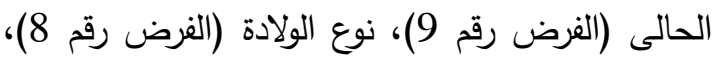
حرية إختيار الزوج (الفرض رقم 13)، أساس إختيار الزواج (الفرض رقم 14) متفقة مع نظرية الزعبة المعيار Norm Theory

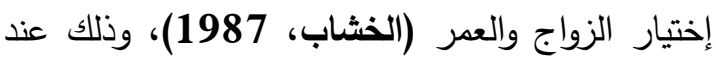

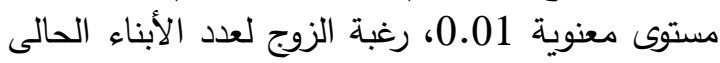

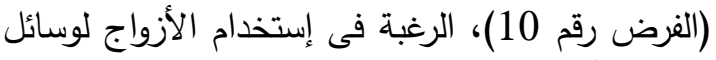

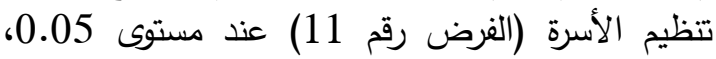
كما تبين عدم وجود علاقة مع متغير الإن المستوى

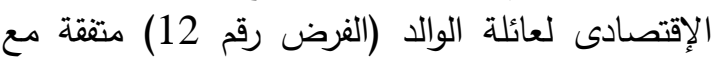
(الطائى والزبيدى، 2014).

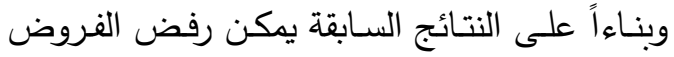
الصفرية وقبول الفروض البديلة بالنسبة للمتغيرات التى التى النى

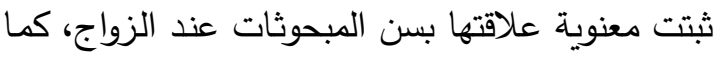

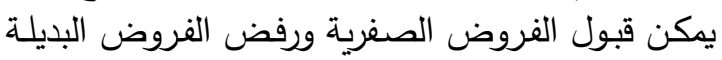

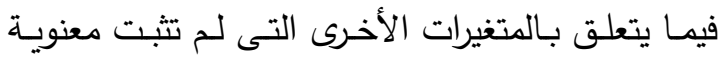
علاقتها.
ثانياً: العلاقة بين سن المبحوثات عند الزواج وبين

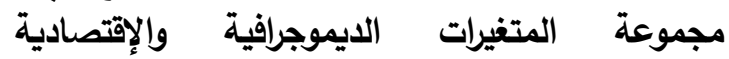
والإجتماعية المدروسة المنيرات

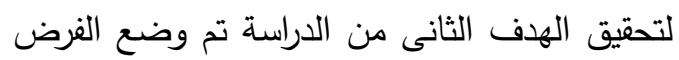

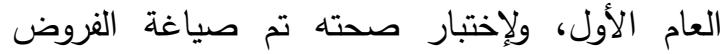

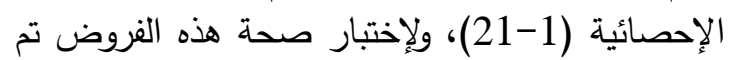

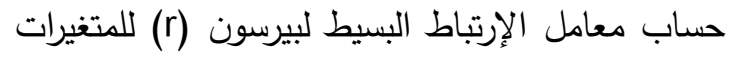

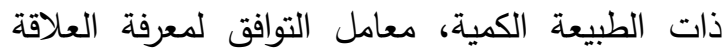
الإقترانية وشدتها للمتغيرات ذات الطعة الطبيعة الإسمية، ويمكن توضيح ذلك فيما يلى:

أ- العلاقات الإرتباطية بين سن المبحوثات عند

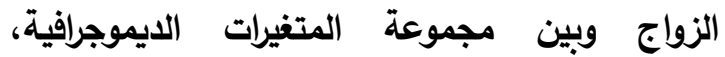

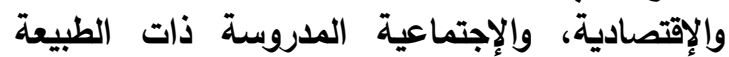
الكمية

يوضـح الجـدول رقـم (7) وجـود علاقـة إرتباطيـة موجبة بين سن المبحوثات عند الزواج وبين متغيرات

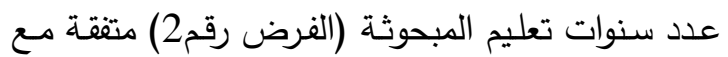

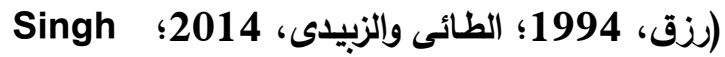
Ahmed et al, 2013 ? and Samara, 1996 :Abdul-Karim and Al-Hadi, 2005 ؛ Choe et !Jensen and Thornton,2003 ؛Field and ambrus, 2008 al, 2004 السـيد، 2011)، عـد سـنوات تعليم الزوج (الفـرض

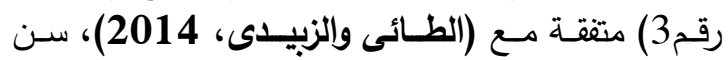

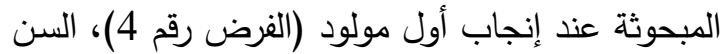

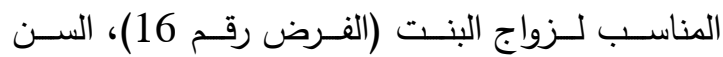

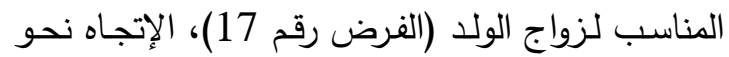

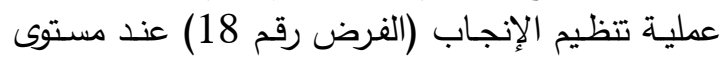

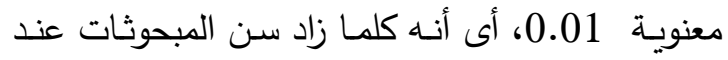

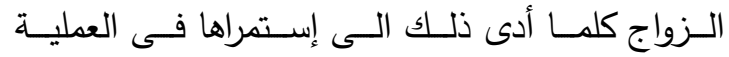

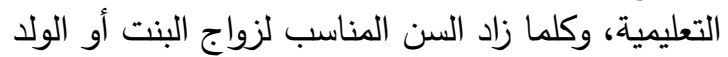

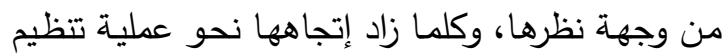
الإنجاب، كما يتضح من الجدول وجود علداد علاقة إرتباطية

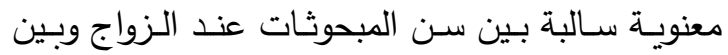

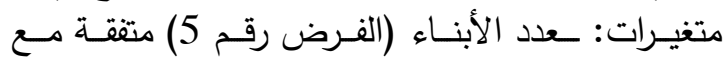
(Abdul-Karim and Al- 1994، (رزق)

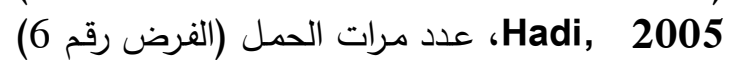


الدخل الشهرى للأسرة (الفرض رقم 23) متفقة مع الأجناه (الطائى والزبيدى، 2014)، الإتجاه نحو قانون تحديد

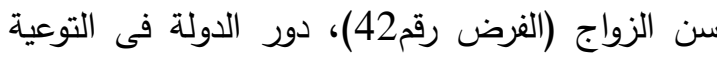

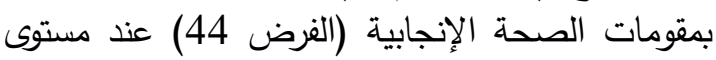

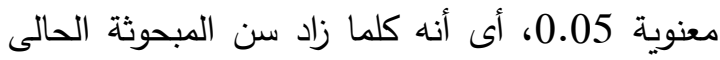

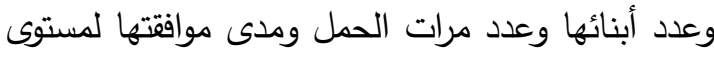

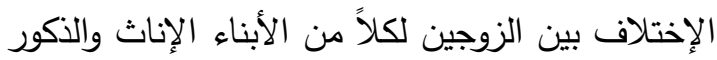

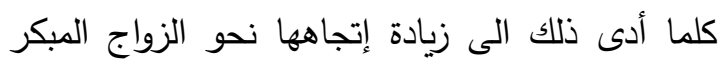

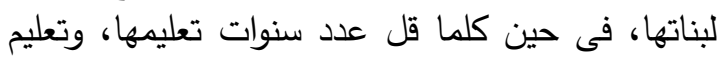

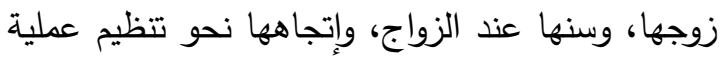

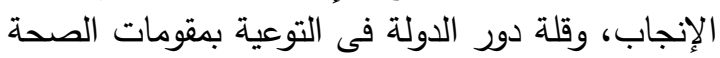

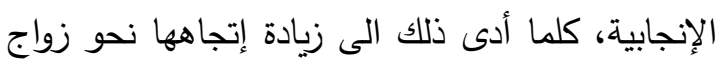

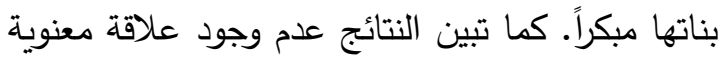

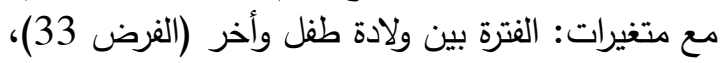

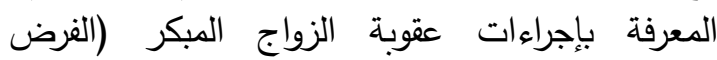

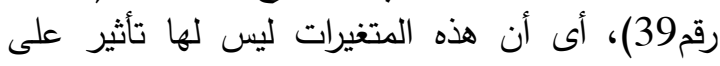
إتجاهات المبحوثات نحو زواج بناتهن.

ب- العلاقات الإقترانية بين إتجاه المبحوثات نحو الإناء

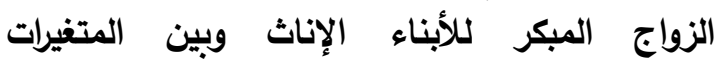
الايموجرافية، والإقتصادية، والإجتماعية المدروسة الإنية ذات الطبيعة الإسمية

يشير الجدول رقم (8) لوجود علاقة توافقية موجبة بين إتجاه المبحوثات نحو الزواج المبكر للأبناء الإناث

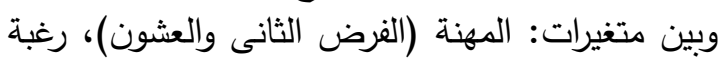

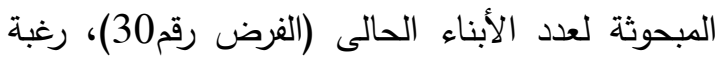

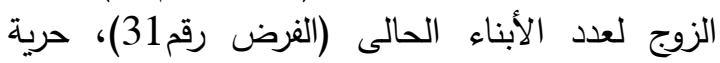
إختيار الزوج (الفرض رقم35)، أساس إختيار الزواج

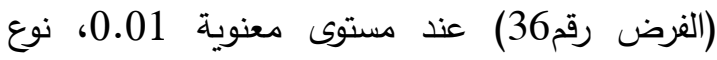
الولادة (الفرض رقم34) عند مستوى معنوية 0.05.

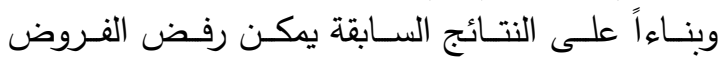

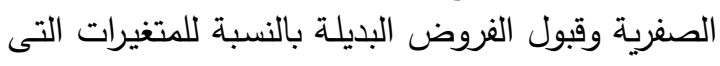

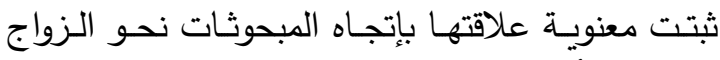

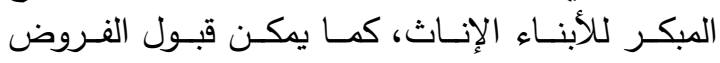

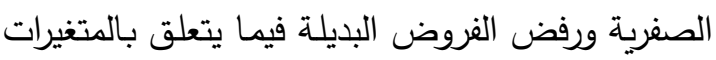
الأخرى التى لم تثبت معنوية علاقتها.
ثاثثاً: العلاقة بين إتجاه المبحوثات نحو الزواج المبكر

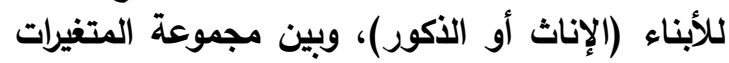

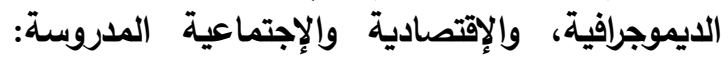
لتحقيق الهدف الثالث للاراسة الراهنة تم وضع الإحتاعة الفرض

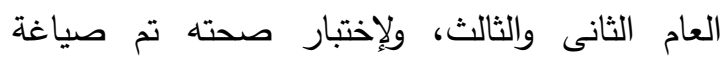

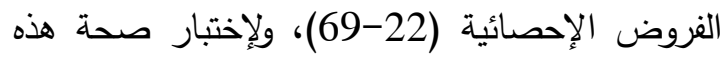

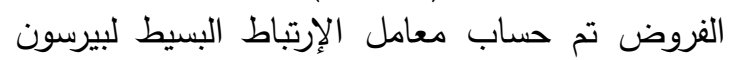
(r) التوافق للعرفة العلاقة الإقترانية وشدتها للمتغيرات ذات ذات المعات الطبيعة الإسمية، ويمكن توضيح ذلك فيما يلى:

1- العلاقة بين إتجاه المبحوثات نحو الزواج المبكر للأبناء الإناث، وبين مجموعة المتفيرات الايموجرافية، الإنية والإقتصادية والإجتماعية المدروسة الإنية

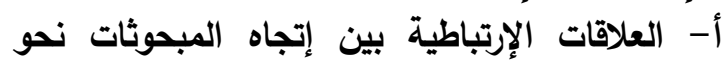

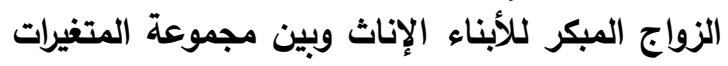
الايموجرافية، والإقتصادية، والإجتماعية المدروسة الإنية ذات الطبيعة الكمية:

إتضح من الجدول رقم (7) وجود علاقة إرتباطية موجبة بين إتجاه المبحوثات نحو الزواج المبات المبكر للأبناء

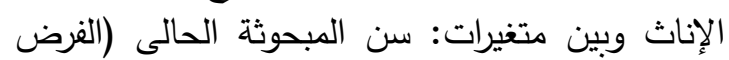

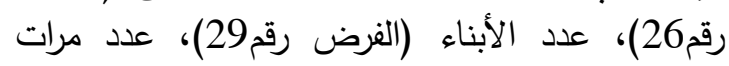

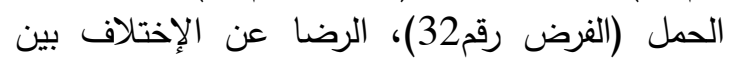

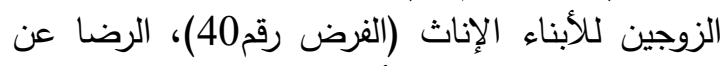

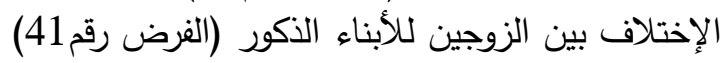

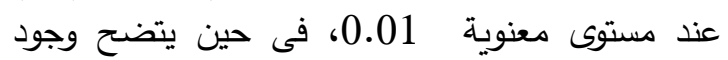
علاقة إرتباطية سالبة مع متغيرات: عدد سنوات تعلية لعنيم

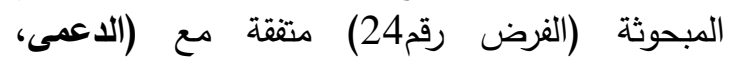

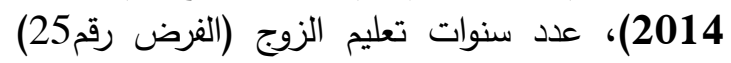

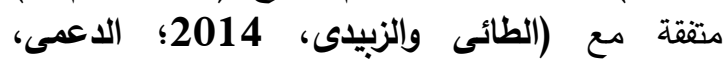
2014)، سن المبحوثة عند الزواج (الفرض رقمر2014)

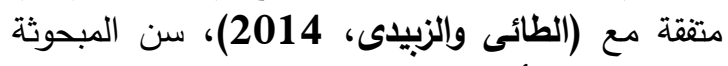

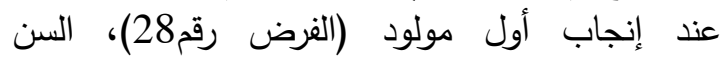

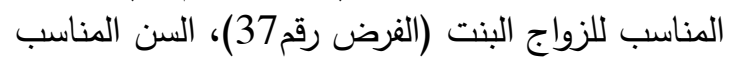
لزواج الولد (الفرض رقم38)، الإتجاه نحو لتظيم عملية الإنية الإنجاب (الفرض رقم43) عند مستوى معنوية 0.01، النجان نحرية 
لا تؤثر على إتجاه المبحوثات نحو زواج أبنائهن

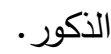

ب- العلاقات الإقترانية بين إتجاه المبحوثات نحو

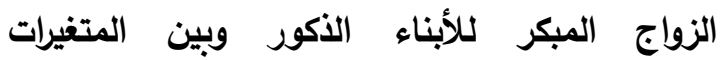
الايموجرافية، والإقتصادية، والإجتماعية المدروسة الإنية ذات الطبيعة الإسمية

يتضح من الجدول رقم (8) وجود علاقة توافقية

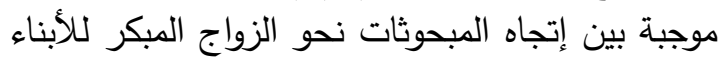

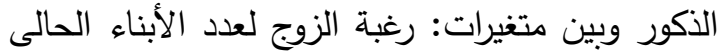

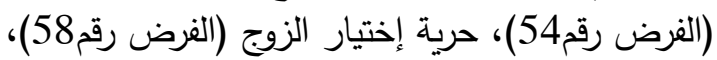
أساس إختيار الزواج (الغرض رقمد معنوية 0.01، فى حين تبين عدم وجود علاقة معنوية الرواجية

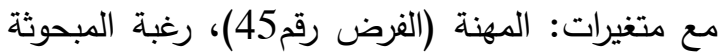
لعدد الأبناء الحالى (الفرض رقم 53 53)، نوع الولادة (الفرض رقم 57). وبنـاءاً على النتائج السـابقة يمكن رفض الفروض الفروض الصفرية وقبول الفروض البديلة بالنسبة للمتغيرات التى

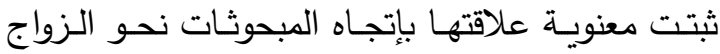

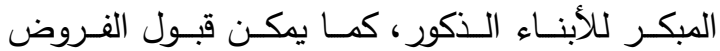

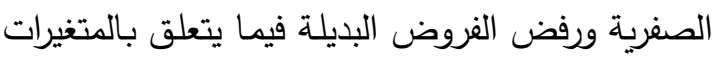
الأخرى التى لم تثبت معنوية علاقتها.

رابعاً: العلاقة بين درجة تطبيق وسائل تنظيم الأسرة،

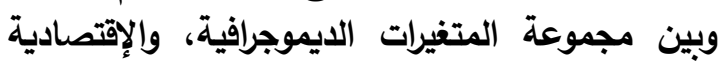
والإجتماعية المدروسة: لتحقيق الهدف الرابع للدراسة

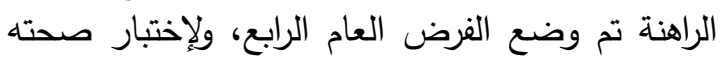
تم صياغة الفروض الإحصائية (68-83)، ولإختبار صحة هذه الفروض تم حساب معامل الإرتباط البسيط ولإنيا لبيرسون (r) للمتغيرات ذات الطبيعة الكمية، وحساب الإتياب معامل التوافق لمعرفة العلاقة الإقترانية وشدتئها

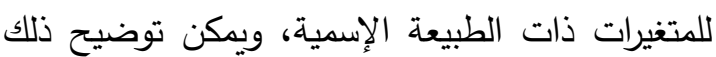

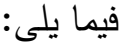

أ- العلاقات الإرتباطية بين درجة تطبيق وسائل تنظيم

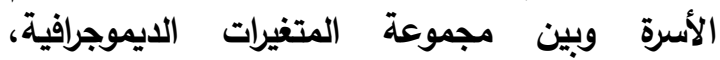
والإقتصادية، والإجتماعية المدروسة ذاتة الطيرات الطبيعة

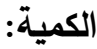

يشير الجدول رقم (7) إلى وجود علاقة إرتباطية موجبة بين درجة تطبيق وسائل تنظيم الأسرة وبين
2- العلاقة بين إتجاه المبحوثات نحو الزواج المبكر

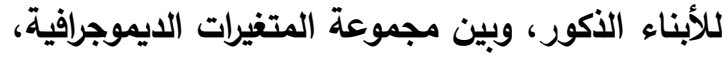
والإقتصادية والإجتماعية المدروسة وبدينة

أ- العلاقات الإرتباطية بين إتجاه المبحوثات نحو

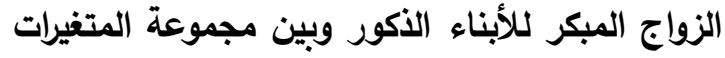

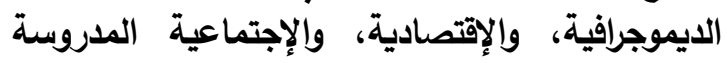
ذات الطبيعة الكمية

يبين الجدول رقم (7) وجود علاقة إرتباطية موجبة

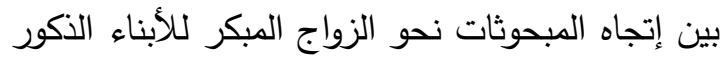

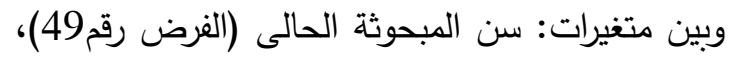

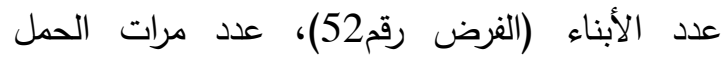
(الفرض رقم55)، الرضا عن الإختلاف بين الزوجين للأبناء الإناث (الغرض رقم

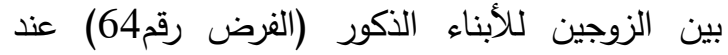

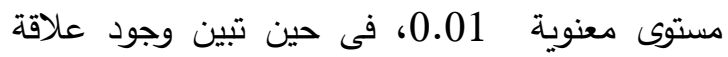
إرتباطية سالبة مع متغيرات: عدد سنوات فين تعليم

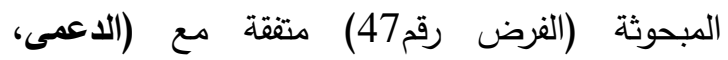

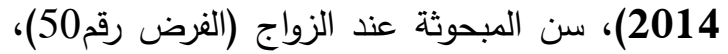

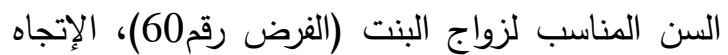

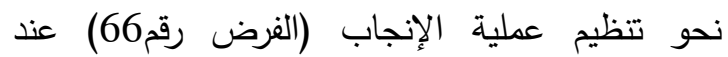
مستوى معنوية 0.01، الدخل الثهرى للأسرة (الفرض الثران

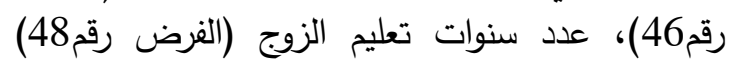
متفقة مع (الدعمى، 2014)، السن المناسب لزواج الزفاج الولد (الفرض رقم 61) عند مستوى 0.05، ألى أنه كلما

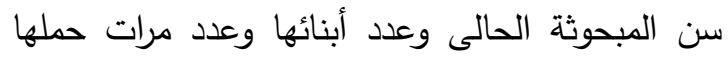

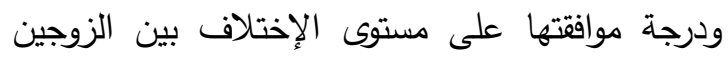

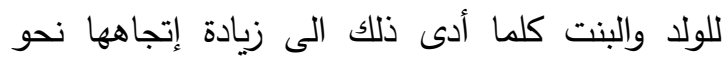

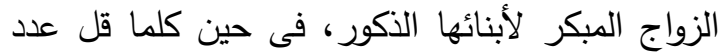

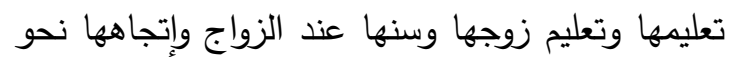

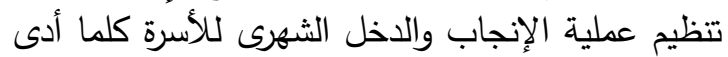
ذلك الى زيادة إتجاهها نحو الزواج النياج المبكر لأبنائها

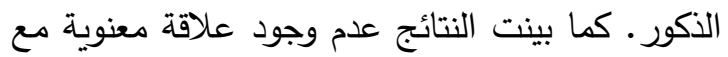

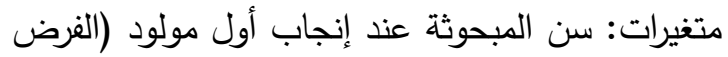

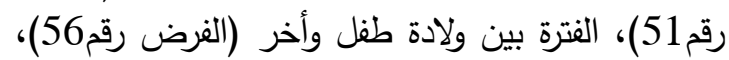

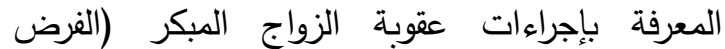
رقم62)، الإتجاه نحو قانون تحديد سن الزواج (الفرض الترواج

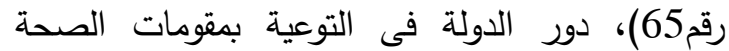
الإنجابية للنساء (الفرض رقم لمك)، أى هذه المتغيرات 
لاى المبحوثة إتجاه إيجابى نحو تنظيم عملية الإنجاب

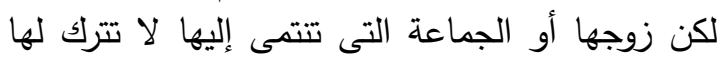

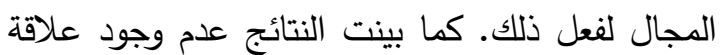

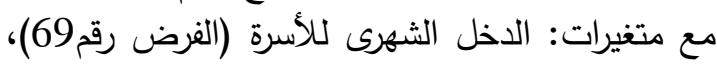

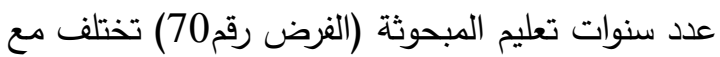
(زكور، 2008/2007) والتى أثارت إلى أن التعليم

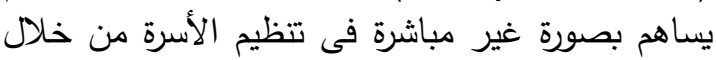
خفض معدلات الخصوبة والإنجاب، (العزاوى وأخرون،

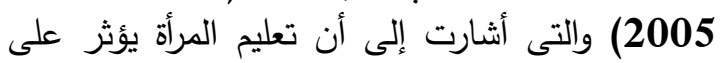
تنظيم الأسرة، عدد سنوات تعليم الزوج (الفرض التفارت رقم تختلف مع (العزاوى وأخرون، 2005) والتئ التئى أشارت

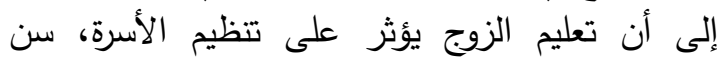

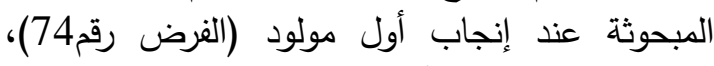

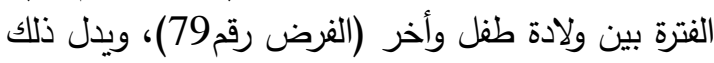

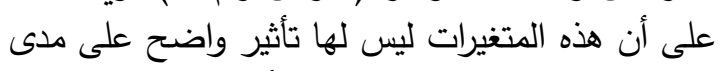
تطبيق المبحوثات لوسائل تتظيم الأسرة.

ب- العلاقات الإقترانية بين درجة تطبيق وسائل تنظيم

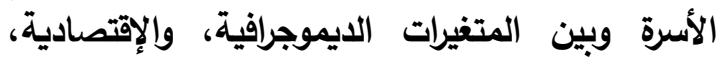
والإجتماعية المدروسة ذات الطبيعة الإسمية الإئية إتضح من الجدول رقم (8) وجود علاقة توافقية

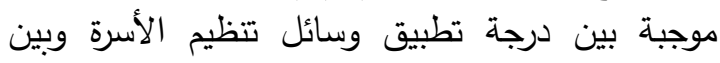

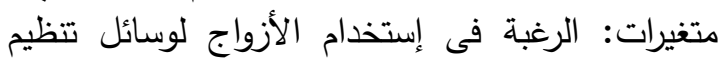

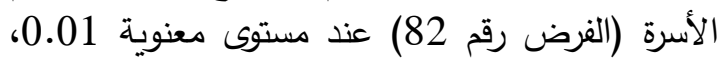

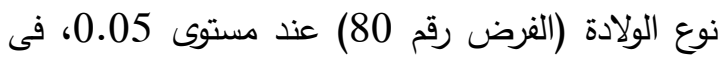

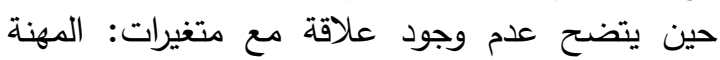
(الفرض رقم68) تتفق مع (العزاوى وأخرون، 2005)

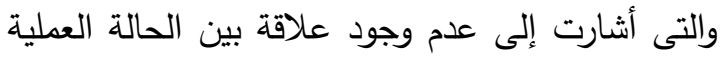

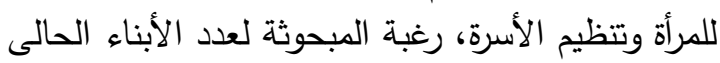

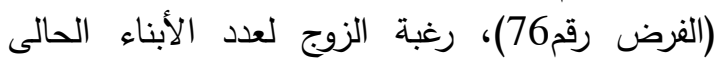

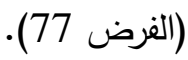

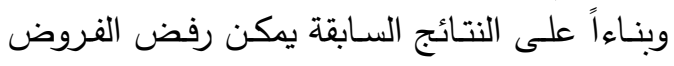

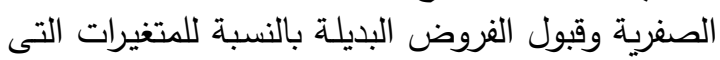

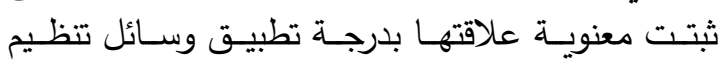

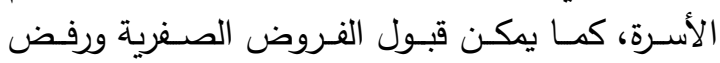
الفروض البديلة فيما يتعلق بالمتغيرات الأخروى التيلى التى لم تثبت معنوية علاقتها.
متغيرات: سن المبحوثة الحالى (الغرض رقم72) تتفق

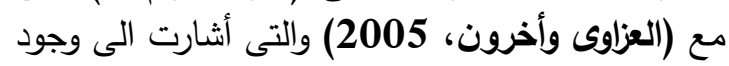

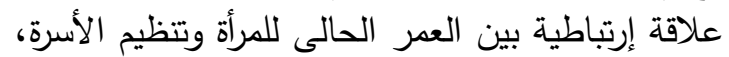

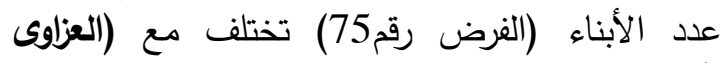

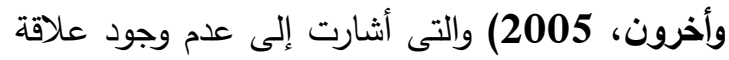

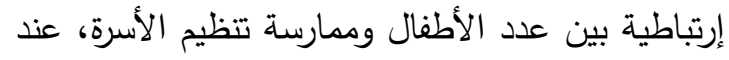

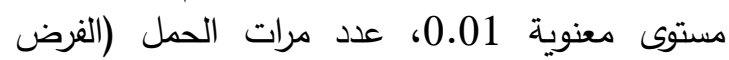

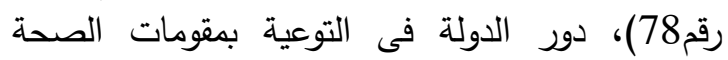

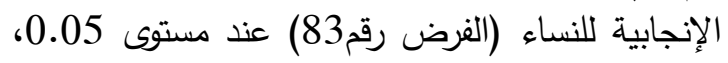

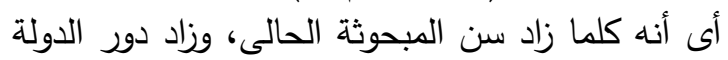

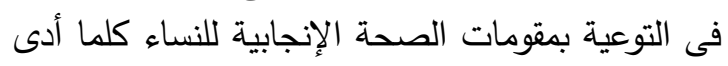

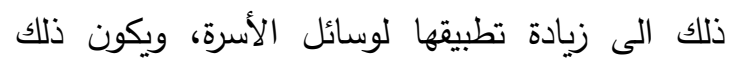

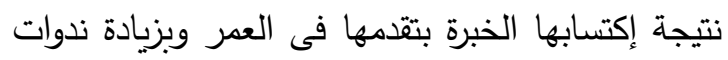
التوعية المقدمة من الدولة. كما أنه كلما زاد عدد أبنائهائها

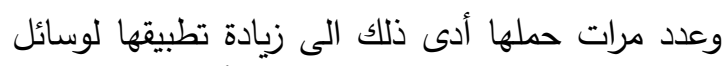

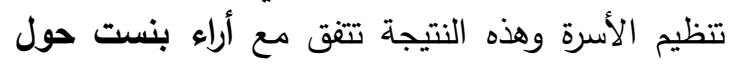
الإغتراب والنفور حيث أنه أشار الى أن الأفراد يدركون أنساء

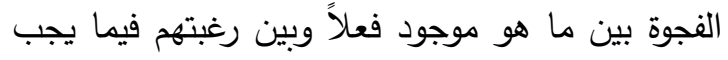

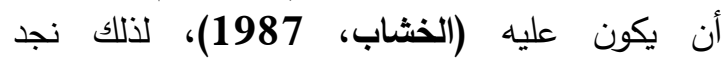

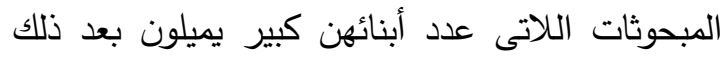

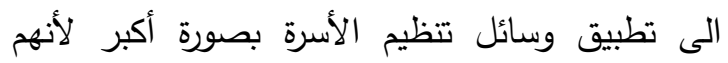

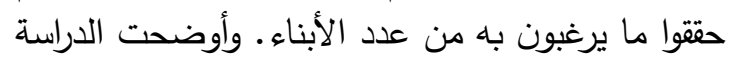

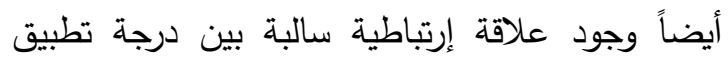

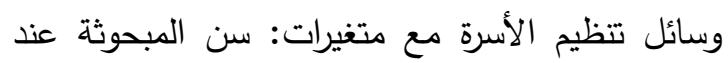

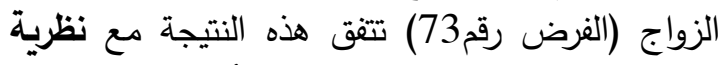

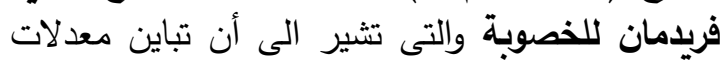

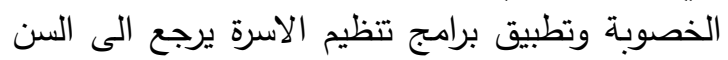

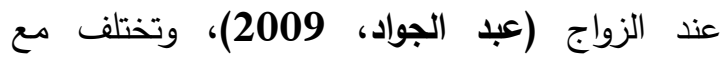

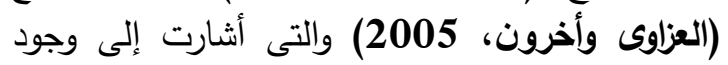
علاقة ارتباطية بين العمر عند الزواج وتتظيم الأنيا الأسرة،

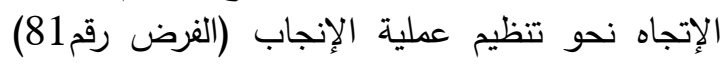
عند مستوى معنوية 0.01، ألى أنه كلما زاد إتجاه إنجاه

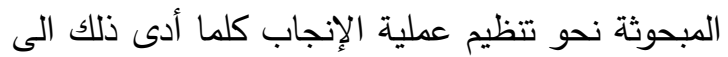

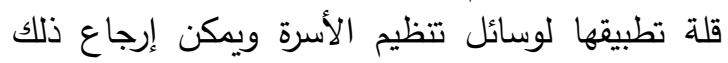

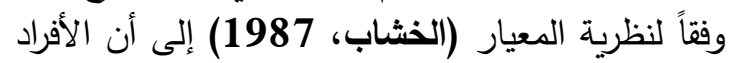

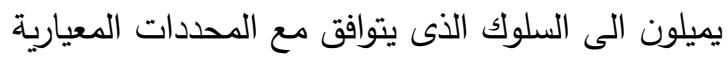
لأفراد الجماعة المنتمين اليها، وبذلك مدكن أن الن يكون الهئ 


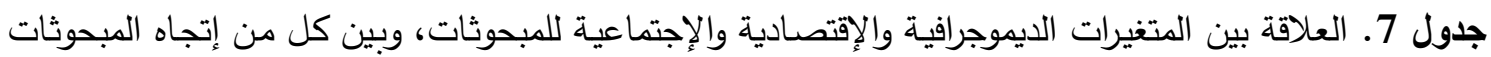

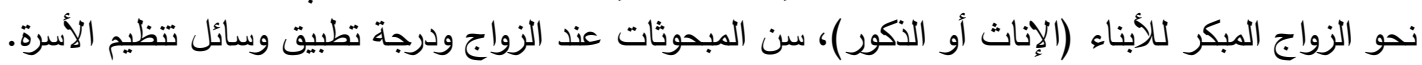

\begin{tabular}{|c|c|c|c|c|}
\hline \multicolumn{4}{|c|}{ معامل الإرتباط البسيط لبيرسون (r) } & \\
\hline درجسائل تطبيق تظيم & سن المبحوثات & الزواج الإتجاه نحو & 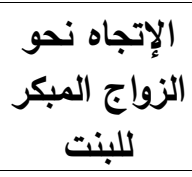 & \\
\hline $0.088^{-}$ & - & *0.169- & $* 0.143-$ & 1-الدخل الشهرى للأسرة. \\
\hline $0.081-$ & $* * 0.542$ & $* * 0.297-$ & $* * 0.343-$ & 2-عدد سنوات تعليم المبحوثة. \\
\hline 0.001 & $* * 0.536$ & $* 0.161-$ & $* * 0.263-$ & 3-عدد سنوات تعليم الزوج. \\
\hline$* * 0.222$ & - & $* * 0.233$ & $* * 0.244$ & 4-سن المبحوثة الحالى. \\
\hline$* * 0.286-$ & - & $* * 0.249-$ & $* * 0.313-$ & 5-سن المبحوثة عند الزواج. \\
\hline $0.133-$ & $* * 0.867$ & 0.097 & $* * 0.262-$ & 6-سن المبحوثة عند إنجاب أول مولود. \\
\hline$* * 0.216$ & $* * 0.497-$ & $* * 0.204$ & $* * 0.272$ & 7-عدد الأبناء. 1 \\
\hline$* 0.163$ & $* * 0.486-$ & $* * 0.221$ & $* * 0.260$ & 8-عدد مرات الحمل. \\
\hline 0.088 & $0.023-$ & 0.043 & 0.033 & 9-الفترة بين ولادة طفل وأخر • \\
\hline- & $* * 0.581$ & $* * 0.196-$ & $* * 0.305-$ & 10-السن المناسب لزواج البنت. \\
\hline 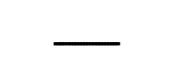 & $* * 0.292$ & $* 0.171-$ & $* * 0.192-$ & 11-السن المناسب لزواج الولد. \\
\hline$\longrightarrow$ & 0.032 & $0.008-$ & $0.087-$ & 12-المعرفة بإجراءات عقوبة الزواج المبكر . \\
\hline & $* * 0.197-$ & $* 0.401$ & $* * 0.507$ & 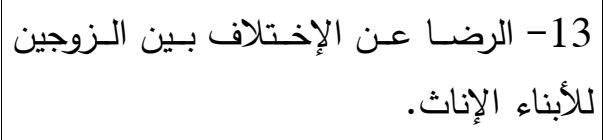 \\
\hline & $* * 0.187-$ & $* * 0.175$ & $* * 0.323$ & لـلأبناء الذكور ـ الرضـا عـن الاخـتلاف بـين الـزوجين \\
\hline & 0.058 & 0.010 & $* 0.140-$ & 15-الإتجاه نحو قانون تحديد سن الزواج. \\
\hline$* * 0.233-$ & $* * 0.286$ & $* * 0.286-$ & $* * 0.402-$ & 16-الإتجاه نحو تتظيم عملية الإنجاب. \\
\hline$* 0.186$ & & $0.088^{-}$ & $* 0.168-$ & الإنجابية. 17-دور الدولة فى التوعية بمقومات الصحة \\
\hline
\end{tabular}




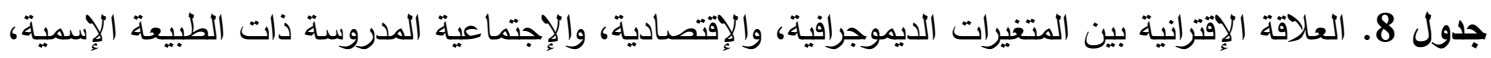

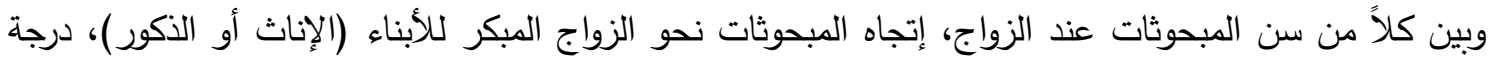
تطبيق وسائل تتظيم الاسرة

\begin{tabular}{|c|c|c|c|c|}
\hline \multicolumn{4}{|c|}{ قيمة معامل التوافق } & \multirow[b]{2}{*}{ المتغيرات } \\
\hline وسائل تنظيم تطبيق & المبكر للأبناء الأكور & المبكر للأبناء الإناثاث & سن المبحوثات الزواج & \\
\hline 0.118 & 0.112 & $* * 0.210$ & $* * 0.401$ & 1-المهنة. \\
\hline 0.171 & 0.194 & $* * 0.291$ & $* * 0.288$ & 2الكباء الحالى المبحوثة ل لعدد \\
\hline 0.150 & $* * 0.263$ & $* * 0.272$ & $* 0.211$ & 3- الأبناء الحالى الزوج ل لعدد \\
\hline *0.205 & 0.200 & *0.211 & $* * 0.356$ & 4-نوع الولادة. \\
\hline & & 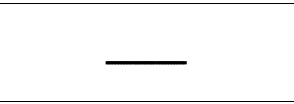 & 0.147 & 5-المستة الوالدى. الإقتصادى \\
\hline- & $* * 0.273$ & $* 0.279$ & $* * 0.297$ & 6- حرية إختيار الزوج. \\
\hline - & $* * 0.299$ & $* * 0.410$ & $* * 0.386$ & 7-أساس إختيار الزواج. \\
\hline$* * 0.309$ & & - & $* 0.253$ & 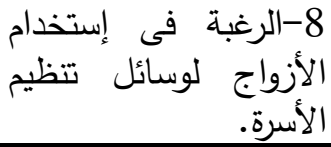 \\
\hline
\end{tabular}

223 ن

إرجاع ذلك إلى أنه ممكن أن تكون فعالية وسائل تنظيم

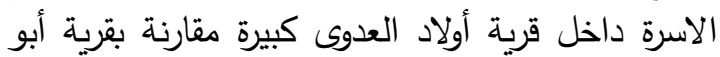

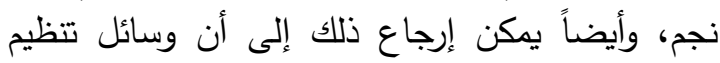

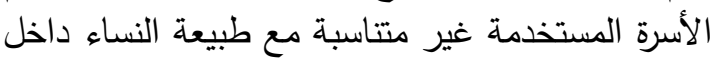

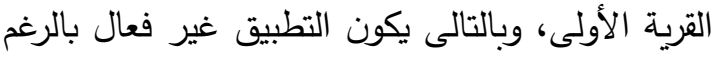

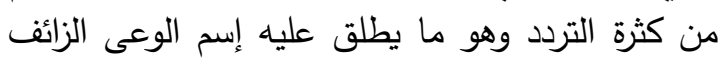

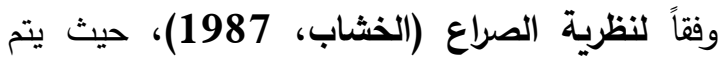

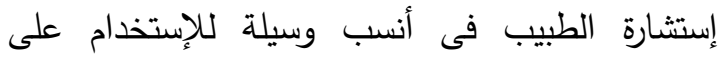

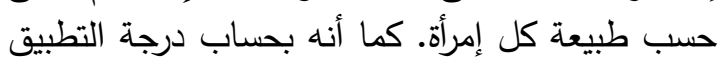

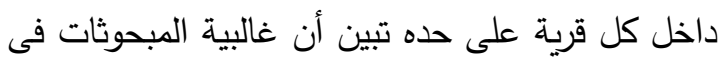

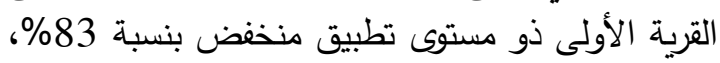

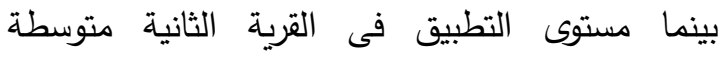

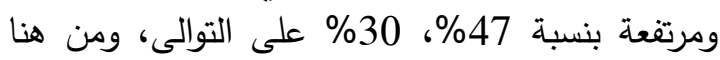
يتضح أنه ليس كل من يتردد على الوحدات الصحية ونلية يطبق بفاعلية.

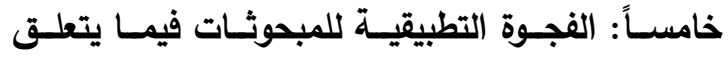

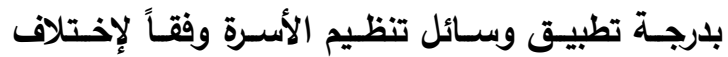

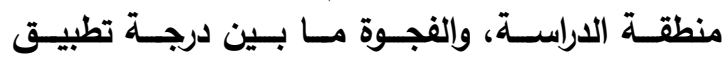

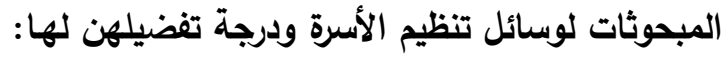

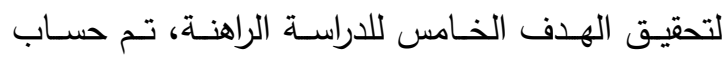

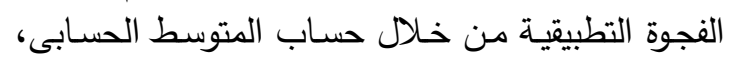

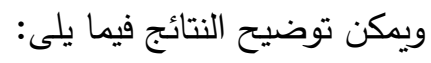

أ- الفجـوة التطبيقيـة للمبحوثـات فيمـا يتعلـق بلرجـة

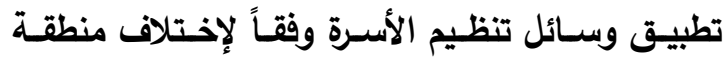

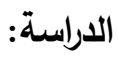

تبين من الجدول رقم (9) وجود فجوة تطبيقية للمبحوثات فيما يتعلق بدرجة تطبيقهن لوسائل تتظيم

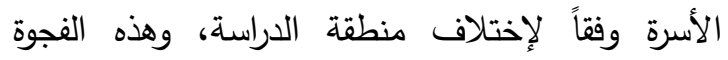

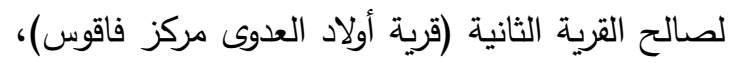

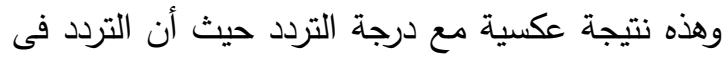
قرية أبو نجم أكبر من التردد فى قرية العدوى، ويمكن 
جدول 9. الفجوة التطبيقية للمبحوثات فيما يتعلق بدرجة تطبيق وسائل تتظيم الأسرة وفقاً لإختلاف منطقة الدراسة، فجوة التطبيق والتفضيل لوسائل تتظم الأسرة

\begin{tabular}{|c|c|c|c|}
\hline الفجوة التطبيقية & متوسط القرية الثانية & الأولى (أبو نجمية) & وسائل تنظيم الأسرة \\
\hline 9.7 & 3.4 & 3.1 & 1- 1 1لولب. \\
\hline 40 & 3.5 & 2.5 & 2-حبوب. \\
\hline 57.9 & 3 & 1.9 & 3-حقن. \\
\hline 38.5 & 1.8 & 1.3 & 4-عازل ذكرى. \\
\hline 25 & 1.5 & 1.2 & 5-الواقى الأنثوى. \\
\hline 36.4 & 1.5 & 1.1 & 6-الحاجز المهبلى للأنثى. \\
\hline 27.3 & 1.4 & 1.1 & 7-الكريم الموضعى. \\
\hline 15.4 & 1.5 & 1.3 & 8-ربط الأنابيب. \\
\hline 16.7 & 1.4 & 1.2 & 9-تعقيم الزوج. \\
\hline صفر & 1.6 & 1.6 & 10-إطالة مدة الرضاعة. \\
\hline 26.4 & 20.56 & 16.30 & الدرجة الكلية لتطبيق وسائل تنظيم الأسبرة \\
\hline 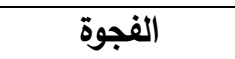 & متوسط التفضيل & متوسط التطبيق & \multirow[t]{2}{*}{ فجوة التطبيق والتفضيل لوسائل تنظيم الأسرة } \\
\hline 24.04 & 13.9 & 18.3 & \\
\hline
\end{tabular}

ب- الفجوة مـا بين درجة تطبيق المبحوثـات لوسـائل

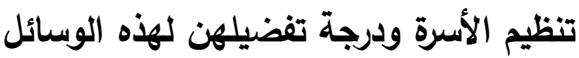

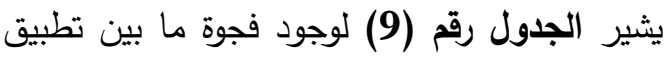

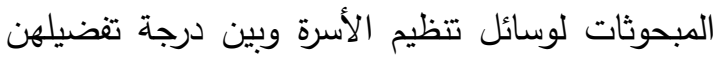
لهذه الوسائل وهذه الفجوة لصالح محور التطبيق.

\section{التوصيات}

بناءاً على ما توصلت إليه الدراسة من نتائج توصى الدراسة بما يلى: 1- توصى الدراسة بضرورة إتخاذ إجراء رسمى فى الإلى محاكم الأحوال الثخصية والتأكد من السن القانونى لتصى (18 سنة) لكل الزوجين عند تسجيل عقود الزواج خاصة عند تسجيل عقود التصادق فى الفئة

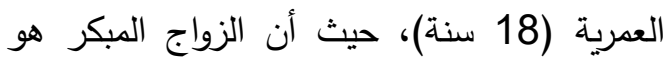

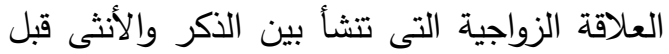
بلوغ السن القانونى، بحيث يتم الإعتماد على ذاتهم

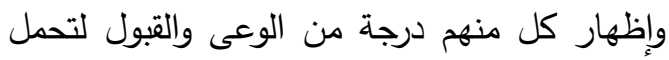

المسئوليات والإلتزامات كل منهما تجاه الأخر، وبذلك يجب التشديد على مكاتب التسجيل.

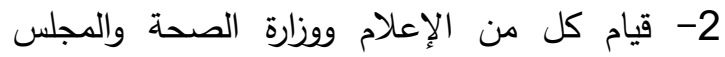

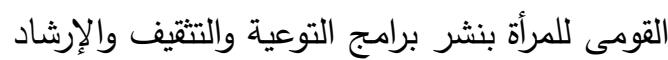

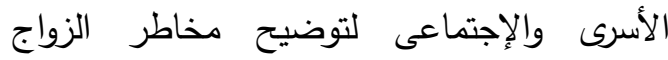
المبكر وأثره على الأبناء والمجتمع، خاصة فيما يتعلق بالجوانب الصحية، وفقدان الحقوق المادية

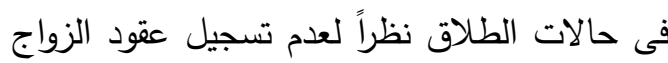

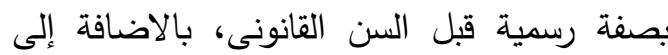

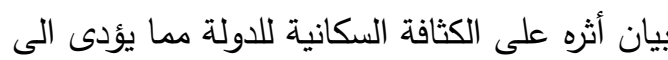
إستتزاف الموارد وعدم كفايتها مع إزدياد هذه الكثافة السكانية. 3- عمل وزارة الصحة على رفع المستوى الصحى وفقاً

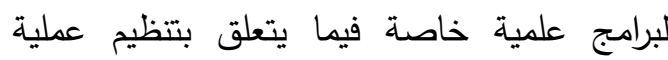
الإنجاب والرعاية الصحية، حيث أوضحت الدراسة الراهنة أن الدولة دورها متوسط فى التوعية التهابة التهاية 
بمقومات الصحة الإنجابية الأمنة للنساء، وذلك من خلال زيادة ندوات التوعية، والقوافل الطبية المستهدفة للمرأة الريفية، بالإضافة الى توفير ندوات لتوات

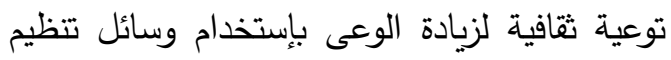
الأسرة بما يتتاسب مع الطبيعة الفسيولوجية لكل

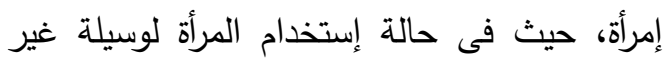

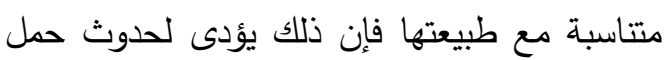

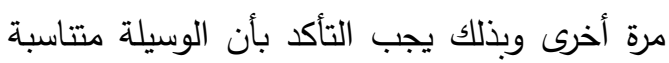
مع طبيعتها لضمان الفاعلية.

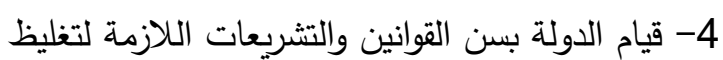
العقوبة على أطباء الصحة الذين يخالفون القانون بإستصدار شهادات وفاة للفتيات وشهادات التسنين.

\section{المراجـع}

اولاً: المراجع باللغة العربية

الأنصارى، أحمد جعفر صادق 2010. "إتجاهات

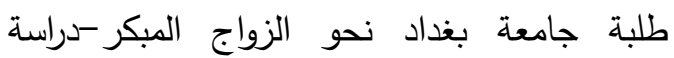
ميدانية"، مجلة كلية الجامعة الإسلامية، الإصدار

\section{2، 133-111،}

الجهاز المركزى للتعبئة العامة والإحصاء 2014- ألأ.

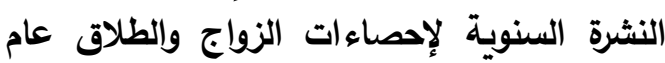

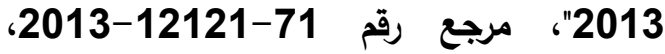

$$
\text { جمهورية مصر العربية. }
$$

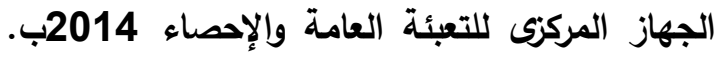

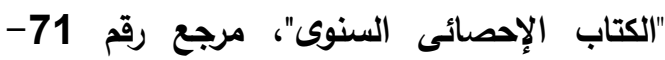

$$
\text { 2014-11110، جمهورية مصر العربية. }
$$

الجهاز المركزى للتعبئة العامة والإحصاء 2016.

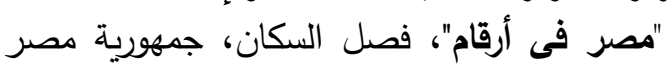

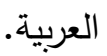

الخثاب، سامية 1987. "النظرية الإجتماعية ودراسة

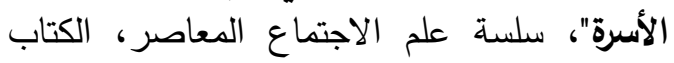

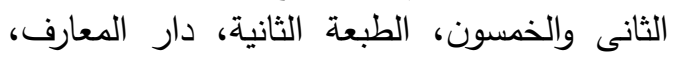

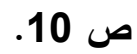

الاعمى، شذى نجاح بلاش 10 2014. الزواج المبكر وعلاقته بالفقر -دراسة ميدانية أنثروبولوجية فى الزئ المبكر
مجمع الخيرات"، لارك للفلسفة واللسانيات والعلوم الإجتماعية، العدد 16، السنة السادسة.

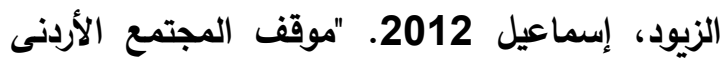

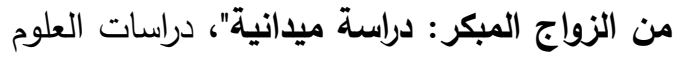

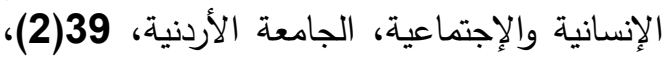
.453-436

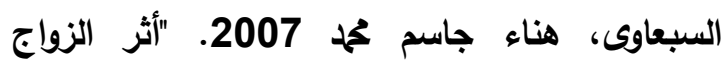
المبكر للفتيات فى عملية التنمية الإجتماعية: دراسة ميدانية فى مدينة الموصل"، دراسات الاجتية

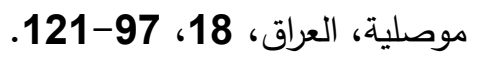
السعدودى، زينب 2008. "موقف 187، الزوجين من

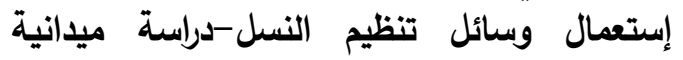

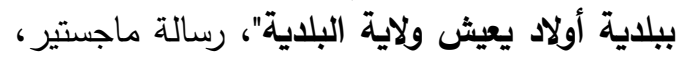

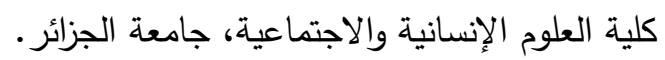

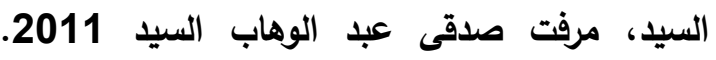
"دراسة بعض مشكلات المرأة بالأسرة الريفية فى الأيل

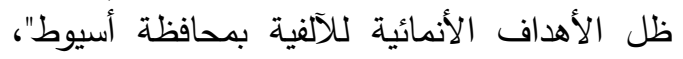

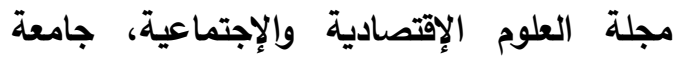

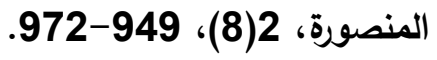
الطائى، لطيف هاشم كزار وعلى حميد دهش الزبيدى

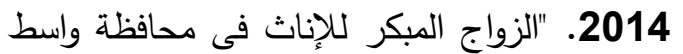

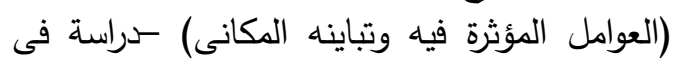
جغرافية السكان"، مجلة كلية التربية / واسط، 15، .360-314

العجمى، مشيرة فتحى عحم وإيناس أسعد رزق 2011. سلوك الأزواج المرتبط بتئنيم إلتئ الأسرة

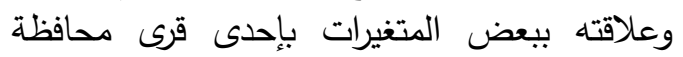

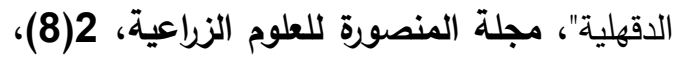
1098-1085

العزاوى، سامى مهاى، محمود محمد سلمان وحذام

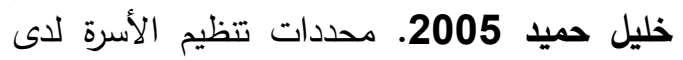

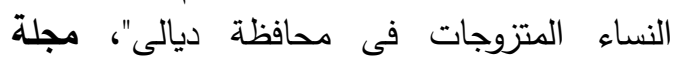
الفتح، 23، 213-224. العموش، أحمد فلاح 2001، 2001- إتجاهات المواطنين نحو

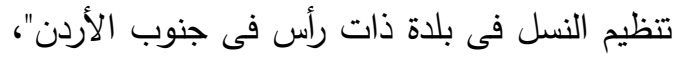

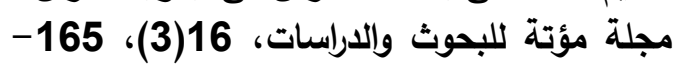
.194 القرآن الكريم، سورة الروم. 
Safe control of soil borne pathogens of bell pepper plants under

plastic-house conditions

القصاص، مهلى محمد 2013. "ظاهرة العنوسة فى المئ المجتمع المصرى سراسة ميدانية"، مجلة العميد، 327-296، 6

المجلس القومى للسكان 2014. 2014. "الإستراتيجية القومية للحد من الزواج المبكر"، بالتعاون مع وزارة الصحة والسكان، جمهورية مصر العربية.

المنظمة العربية للتمية الزراعية 1997. مساهمة التنظيمات النسوية في التمية تنمية المرأة الريفية ووثيقة المشروع المتكامل لتطويرها"،

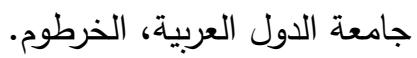

بركات، حما محمود، مجدى لإنى على يحيى وجاسنت إبراهيم ريحان 2003. بحات "الزواج المبكر للفتيات وعلاقته ببعض مؤشرات الصحة الإنجابية للمرأة الريفية فى قرية عرب مطير -محافظة أسيوط"،

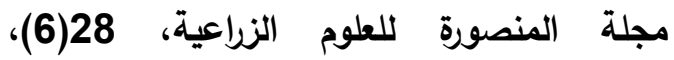
.4545-4529

رزق، إبراهيم أحمد 1994-4529. السن عند الزواج الأول

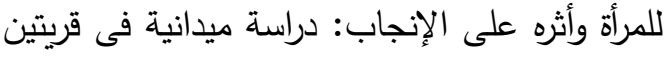

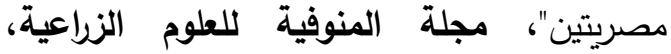

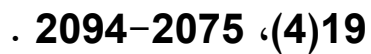
زكور، 2008/2007. "دور التعليم العالى فى تنظيم

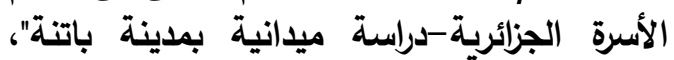
رسالة ماجستير، كلية العلوم الإنسانية والعلوم لإنية

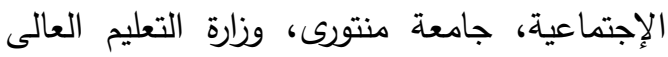
والبحث العلمى، الجزائر . زكى، إنتصار عبد العزيز وسماح عبد الفتاح عبد

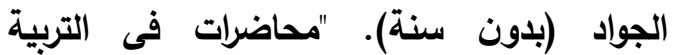
الأسرية"، محاضرات غير منشورة، كلية التربية

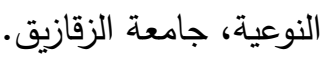

سليم، أمل داود وشيماء حارث إنمازئ 2015. "الزواج المبكر لمن هم دون سن 18 سنة ظاهرة من الهن ظواهر العنف الأسرى ضد الأطفال-دراسة ميدانية لاى عينة من طالبات قسم رياض الأطفال"، مجلة البحوث التربوية والنفسية، 47، 4الت 26 2012-49.

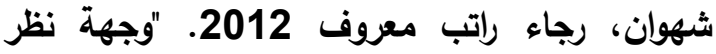
سكان محافظة قلقيلية فى الزواج المبكر للإناث"،

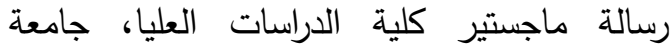
النجاح الوطنية، نابلس، فلسطين.
شوقى، شيرين ووليد ملعاط 2000. "زواج المراهقات

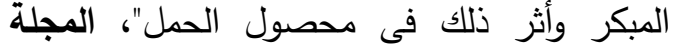
الصحية لثرق المتوسط، منظمة الصحة العالمية،

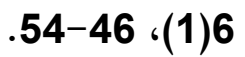

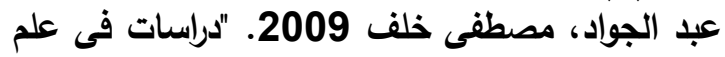
إجتماع السكان"، دار المسيرة. علام، صلاح الدين محمود 1985. "تحليل البيانات البيات

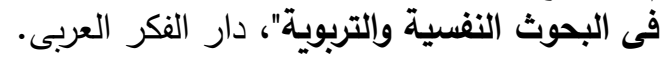

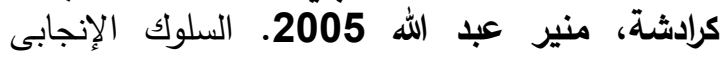

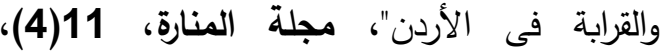
.463-417

مركز المعلومات ودعم إتخاذ القرار 2015. "بيان بتنظيم الأسرة والطب الوقائى"، محافظة الشرقية.

ثانياً: المراجع باللغة الانجليزية

Abdul-Karim, E.T. and Al-Hadi, A. 2005. "Mother Age At Marriage As A Determinant Of Reproductive Health", Iraqi Journal of Medical Sciences, 4(1), 57-62.

Ahmed. S., Khan, S., Alia, M. and Noushad, S. 2013. Psychological Impact Evaluation of Early Marriages", International journal of endorsing health science research, 1(2), 84-86.

Choe, M.K., Thapa, S. and Mishra, V. 2004. Early marriage and early motherhood in Nepal', J. biosoc. Sci., Cambridge University Press.

Field, E. and Ambrus, A. 2008. "Early Marriage, Age of Menarche, and Female Schooling Attainment in Bangladesh", Journal of Political Economy, 116(5), 881-930.

Jensen, R. and Thornton, R. 2003. "Early Female Marriage In The Developing World", Gender and Development, 11(2), 9-19.

Singh.S and Samara, R. 1996. Early Marriage Among Women in Developing Countries", International Family Planning Perspectives, 22(4), 148-157. 


\title{
EARLY MARRIAGE AND ITS IMPACT ON THE PLANNING OF THE REPRODUCTIVITY PROCESS IN RURAL SHARKIA GOVERNORATE
}

\author{
Huda A.E. El-Deeb and Sahar M.Sh. Newaser \\ Branch of Rural Sociol., Agric. Economic Dept., Fac. Agric., Zagazig Univ., Zagazig, Egypt
}

about early marriage for girls, while more than half respondents have neutral attitud about early marriage for the son by $60.5 \%$. and prove the existence of a significant relationship between the age of the respondents at marriage and variables: the number of years of education for the respondents, the number of years of education for the husband, the age at first birth, the suitable age of marriage for girls, the suitable age for boys, The attitud toward the planning of the process of reproduction. The results indicate existence of negative relationship between the age at marriage and variables: the number of children, number of pregnancies, satisfaction with the difference between couple for the girl, satisfaction with the difference between couple for their sons. The study also found that $94.2 \%$ of respondents have neutral and positive attitude toward regulating the reproductive process, while shows that the highest percentage of respondents neutral and positive attitude toward reproductive process. The results indicate that $49.8 \%$ of the respondents have negative attitude for preference and $49.3 \%$ for the application and there are gap between the application of the respondents to the methods for family planning and the degree of preference for these methods.
Keywords: Early Marriage, The Planning Of The Reproductive Process, Birth Control, Sharkia Governorate

\section{ABSTRACT}

The study aimed to identify the causes of early marriage for the children, his methods, and identify his effects. to determine the relationship between the age of the respondents at marriage, the Attitude of respondents toward early marriage for the daughter / son and the demographic, economic and social variables. To Determine the relationship between the application of the respondents to family Planning methods and the demographic, economic and social variables. to determine the respondents Application gap regarding the application of family Planning methods, according to different regions of the study. to identify the respondents application gap of family Planning methods and the degree of preference for these methods. The study was conducted depending on the social survey method in the villages of Kafr Abu Najm and Awlad Eiladawy in Sharkia governorate on a random sample of 223 units represens $5 \%$ of the total number of women in each village, and collected data using a questionnaire by personal interview, starting from April until late of June 2016, data were analyzed using frequencees and percentages, alpha Cronbach's coefficient, weighted mean, Pearson correlation coefficient, contingency coefficient, the expense of applied gap.

The study found a range of resalts including: that early marriage percentage (less than 18 years) in the field study amounted to $36.3 \%$, showing that about $43.5 \%$, and $49.8 \%$ of the respondents have negative attitud and neutral 